DOI: $10.19195 / 0080-3626.60 .5$

\author{
JACEK PUCHALSKI
}

\title{
PRZEGLĄD BADAŃ NAD HISTORIĄ BIBLIOTEK I BIBLIOTEKARSTWA W POLSCE Z LAT 1945-2015
}

Intensyfikacja badań nad historią bibliotek i bibliotekarstwa od połowy lat 50. XX wieku. Monografie, artykuły problemowe, zarysy, prace popularnonaukowe wnoszące trwałe wartości merytoryczne i metodologiczne do dorobku polskiej bibliologii, powstałe dzięki rozbudowie podstawy źródłowej studiów oraz rozwojowi refleksji źródłoznawczej i metodologicznej.

SŁOWA KLUCZOWE: historia bibliotek, historia bibliotekarstwa, biblioteki, Polska

Opisywana problematyka była omawiana w wielu publikacjach na temat studiów bibliologicznych i bibliotekoznawczych ${ }^{1}$. Całościowy, retrospektywny prze-

${ }^{1}$ M.in. Aleksander BIRKENMAJER, Bibliotekoznawstwo polskie: jego przeszłość, stan obecny i perspektywy na przyszłość, [w:] idem, Studia bibliologiczne. Wybór tekstów pod red. Heleny Więckowskiej i Aleksandry Birkenmajer, Wrocław: Zakład Narod. im. Ossolińskich. Wydaw. PAN 1975, s. 33-79; Historia ksiązki i bibliotek oraz ich stan obecny w Polsce. Red. Krystyna Remerowa i Aleksandra Szabuniewiczowa, Warszawa: SBP 1959; Helena WIĘCKOWSKA, Organizacja, stan i kierunki badań bibliologicznych 1945-1967, Przegląd Biblioteczny 1968, z. 1/2, s. 45-77; Paulina BUCHWALD-PELCOWA, Badania nad historia polskiej ksiażki drukowanej XV-XVIII wieku, Przegląd Biblioteczny 1974, z. 4, s. 371-390; Elżbieta SŁODKOWSKA, Stan badań nad historia ksiązki polskiej pierwszej polowy XIX wieku, Przegląd Biblioteczny 1974, z. 4, s. 391-401; Marian J. LECH, Stan badań nad historia ksiązki polskiej 1850-1918, Przegląd Biblioteczny 1974, z. 4, s. 403-412; Jadwiga KOŁODZIEJSKA, Współczesne kierunki badań bibliotekoznawczych, Roczniki Biblioteki Narodowej (12/13) 1976/1977, s. 155-164; Barbara BIEŃKOWSKA, Wiedza o dawnej ksiązce. Przegląd i ocena literatury dydaktycznej, Przegląd Biblioteczny 1983, z. 2/3, s. 199-205; Krzysztof MIGOŃ, Nauka o książce. Zarys problematyki, Wrocław: Zakład Narod. im. Ossolińskich. Wydawnictwo 1984, s. 148-154, 156-161; Edward POTKOWSKI, Ksiażka w komunikacji społecznej wieków średnich. Stan i znaczenie badań u progu XXI wieku, [w:] Nauka o książce, bibliotece i informacji we współczesnym świecie. Red. Marianna Banacka, Warszawa: SBP 2003, s. 57-63; Studia o Książce (17) 1988 z artykułami na temat stanu badań nad historią książki Mazowsza (Marianna MLEKICKA i Józef WOJAKOWSKI, s. 35-53), Kielecczyzny (Czesław ERBER, s. 79-98), Wielkopolski (Bogumiła KOSMANOWA, s. 55-77), Krakowa w XIX-XX wieku (Maria KOCÓJOWA, s. 217-245), Pomorza Gdańskiego (Zbigniew NOWAK, s. 127-157) i Gdańska w XVIII wieku (Elżbieta PIOTROWSKA, s. 159-172), Warmii i Mazur (Jan 
gląd badań nad samymi dziejami bibliotek przedstawiła w 1980 roku Bogumiła Kosmanowa $^{2}$, dlatego skupię się na omówieniu prac wydanych od początku lat 80. XX wieku, cytując jednak ważniejsze rozprawy, które ukazały się wcześniej. Uwzględniam zatem tylko publikacje, i to w subiektywnym wyborze, być może nie zawsze najtrafniejszym.

\section{PODSTAWA ŹRÓDŁOWA BADAŃ}

W referacie z 1950 roku Aleksander Birkenmajer podkreślił, że postęp w badaniach księgoznawczych zależy m.in. od rozwoju prac dokumentacyjno-źródłowych i informacji o zbiorach ${ }^{3}$. Od tego czasu poszczególne biblioteki polskie udostępniały informacje o swoich najważniejszych zasobach historycznych, przyczyniając się do rozwoju studiów m.in. nad przeszłością bibliotek. Natomiast na pełne opracowanie i publikację swoich inwentarzy i katalogów czekają zbiory polskie przechowywane za granicą, pochodzące z bibliotek funkcjonujących w przeszłości na terytorium Rzeczypospolitej ${ }^{4}$ i na ob-

WRÓBLEWSKI, s. 99-125), Dolnego Śląska (Kazimiera MALECZYŃSKA, s. 173-291), Litwy (Henryk DUBOWIK, s. 247-266) i Lwowa w XVI-XVIII wieku (Edward RÓŻYCKI, s. 271-286). Tom otwiera artykuł B. BIEŃKOWSKIEJ, Badania regionalne w historiografii ksiązki, s. 17-33.

2 B. KOSMANOWA, Przeglad badań nad historia bibliotek $w$ Polsce, Rocznik Biblioteki Narodowej (16) 1980, s. 47-78. Zob. też m.in. Krystyna ZAWADZKA, Ze źródet i stanu badań dotyczacych dawnych klasztornych bibliotek dominikanów w polskich prowincjach, Nasza Przeszłość (39) 1973, s. 213-228; E. RÓŻYCKI, Stan i zadania badań nad dziejami księgozbiorów mieszczan lwowskich XVI-XVII w., Roczniki Biblioteczne (23) 1979 z. 2, s. 1-23; K. MALECZYŃSKA, Biblioteki mieszczańskie $w$ dawnej Polsce. Stan badań - problematyka - postulaty badawcze, [w:] 500-lecie polskiego słowa drukowanego na Śląsku. Materiały sesji naukowej, 9-11 X 1975, Wrocław, Wrocław: Wydaw. Uniwersytetu Wrocławskiego 1978, s. 23-40; eadem, Stan badań nad historia bibliotek polskich doby zaborów oraz ich podstawa źródłowa, [w:] Z dziejów udostęniania ksiązki w Polsce w okresie zaborów. Studia i materiaty. Pod red. Kazimiery Maleczyńskiej, Wrocław: Wydaw. Uniwersytetu Wrocławskiego 1985, s. 5-36; Zofia GACA-DĄBROWSKA, Sytuacja $w$ badaniach nad dziejami bibliotek $i$ bibliotekarstwa XIX $i$ XX w., Studia o Książce (12) 1982, s. 67-87; Krystyna BEDNARSKA-RUSZAJOWA, Jan PIROŻYŃSKI, Forschungsstand zur Geschichte polnischer privatbibliotheken im 18. Jahrhundert, Wolfenbütteler Notizen zur Buchgeschichte (1) 1993/1994, s. 37-51; Jolanta GWIOŹDZIK, Biblioteka w kulturze zakonnej. Zarys problematyki, [w:] Biblioteki kościelne i klasztorne w Polsce. Historia i wspótczesność. Red. Henryk Olszar, Bogumiła Warząchowska, Katowice: Wydział Teologiczny Uniwersytetu Śląskiego 2009, s. 53-62.

3 A. BIRKENMAJER, op. cit., s. 67-68. Zob. też m.in. Zofia CIECHANOWSKA, Aleksander Birkenmajer o historii bibliotek, Roczniki Biblioteczne (13) 1969, s. 223-238.

${ }^{4}$ Np. Józef TRYPUĆKO, The catalogue of the books of the Jesuit College in Braniewo held in the University Library in Uppsala. Katalog księgozbioru Kolegium Jezuitów w Braniewie zachowanego w Bibliotece Uniwersyteckiej w Uppsali. Vol. 1. Introduction, manuscripts, incunabula. Vol. 2. The 16th and 17th century books. Vol. 3. Indexes. Extended and compl. by Michał Spandowski. Ed. by Michał Spandowski, Sławomir Szyller. Warszawa: Biblioteka Narodowa; Uppsala: 
czyźnie ${ }^{5}$. Informacje o dawnych księgozbiorach (w tym ich spisy, inwentarze i katalogi) publikowano w postaci wydawnictw samoistnych (m.in. Jadwiga Rudnicka ${ }^{6}$ ), w monografiach oraz na łamach periodyków poszczególnych bibliotek $^{7}$ i innych ośrodków ${ }^{8}$. Należy także podkreślić postęp w opracowaniu proweniencyjnym materiałów do końca XVIII wieku. Prace nad Narodowym Zasobem Bibliotecznym przyczynią się zapewne do rejestracji pozostałości po wielu księgozbiorach z XIX-XX wieku9 .

Poszerzenie podstawy źródłowej badań umożliwia obecnie Internet. Przykładem mogą być bazy: Manuscripta.pl, zawierająca informacje o rękopisach powstałych do 1530 roku, znajdujących się w zbiorach polskich i zagranicznych, z uwzględnieniem danych dotyczących ich proweniencji ${ }^{10}$ — projekt nawiązujący do postulatu Edwarda Potkowskiego sporządzenia wykazu właścicieli i użytkowników książki na terenie Polski w wiekach średnich ${ }^{11}$; Katalog starych druków Biblioteki Ordynacji Nieświeskiej Radziwiłłów. Druki polskie XVI-XVIII w., Centrum Badawczego Bibliografii Polskiej Estreicherów ${ }^{12}$ oraz Biblioteki po skasowanych klasztorach... Gabinetu Starych Druków Biblioteki Uniwersyteckiej w Warszawie ${ }^{13}$.

Uppsala Universitetsbibliotek 2007; Catalogue of books from the Library of Sigismund II Augustus, King of Poland, in the collection of the National Library of Russia in Saint Petersburg. Ed. by Maria I. Tkachenko, Maria Brynda, Warsaw: National Library of Poland 2015, 198, [1].

${ }^{5}$ Z nowszych publikacji zob. np. Katalog starych druków biblioteki Papieskiego Kolegium Polskiego w Rzymie. Oprac. Michał Spandowski; proweniencje oprac. Joanna Borysiak, Warszawa: Biblioteka Narodowa 2010.

${ }^{6} \mathrm{~Np}$. Inwentarz biblioteki Ignacego Krasickiego z 1810 r. Oprac. Sante Graciotti, Jadwiga Rudnicka, Wrocław: Zakład Narod. im. Ossolińskich. Wydaw. Polskiej Akademii Nauk 1973.

$7 \mathrm{~Np}$. Władysława JABŁOŃSKA, Inwentarze i katalogi biblioteczne w zbiorach rękopiśmiennych Biblioteki Zakładu Narodowego im. Ossolińskich, Ze Skarbca Kultury (15) 1969, z. 20, s. 73-179; Dobrochna BOLEWSKA, Ryszard MARCINIAK, Katalogi i inwentarze ksiażek w zbiorach rękopiśmiennych Biblioteki Kórnickiej. Cz. I. Katalogi i inwentarze do roku 1800. Oprac. Ryszard Marciniak, Pamiętnik Biblioteki Kórnickiej 1988, z. 22, s. 157-172.

8 Zob. np. Artur HAMRYSZCZAK, Prace Ośrodka Archiwów Bibliotek i Muzeów Kościelnych $w$ zakresie dokumentowania zbiorów bibliotek klasztornych, Archiwa, Biblioteki i Muzea Kościelne (99) 2013, s. 19-28.

9 Zob. Artur JAZDON, ,Zaginione” kolekcje w zbiorach Biblioteki Uniwersyteckiej w Poznaniu na przykładzie Biblioteki Batignolskiej, [w:] Dziedzictwo utracone — dziedzictwo odzyskane. Red. nauk. Anna Kamler, Dorota Pietrzkiewicz, Warszawa: Oficyna Wydawnicza Aspra-JR 2014, s. 261-271.

10 About us, http://manuscripta.pl/?page_id=9 [dostęp: 12 III 2016].

11 E. POTKOWSKI, Książk i pismo w średniowieczu. Studia z dziejów kultury piśmiennej i komunikacji społecznej, Pułtusk: Akademia Humanistyczna im. Aleksandra Gieysztora 2006, s. 360.

12 http://www.estreicher.uj.edu.pl/bazy_bibliograficzne/ [dostęp: 3 III 2016].

$13 \mathrm{Na}$ ten temat zob. Izabela WIENCEK, Zakończenie pierwszego etapu prac nad baza online oraz przewodnikiem Biblioteki po skasowanych klasztorach: historia, znaki własnościowe, źródta, Hereditas Monasteriorum (2) 2013, s. 509-513. 
Historycy sięgnęli do źródeł aktowych przechowywanych w archiwach państwowych $^{14}$ i kościelnych ${ }^{15}$ nie tylko dla ich użyteczności, lecz także z powodu fragmentaryczności, nieraz szczątkowości zachowanej dokumentacji bibliotecznej i właścicieli bibliotek ${ }^{16}$. Wartościowe materiały o przeszłości bibliotek i bibliotekarstwa zgromadziły też wyspecjalizowane placówki, w tym: Państwowy Instytut Książki, a po jego likwidacji w 1949 roku — Pracownia Dokumentacji Księgoznawczej Biblioteki Narodowej; Pracownia Stownika pracowników książki polskiej przy Katedrze Bibliotekoznawstwa i Informacji Naukowej Uniwersytetu Łódzkiego oraz Pracownia Dokumentacji Księgozbiorów Historycznych BN (1990-2009) powołana m.in. do przygotowania Informatora o polskich ksiegozbiorach historycznych i powstatych na ziemiach polskich do 1950 r. ${ }^{17}$ Po 1989 roku nasilono poszukiwania źródeł w zbiorach zagranicznych, zwłaszcza na Litwie, Białorusi, Ukrainie, w Rosji i Niemczech ${ }^{18}$, lecz pierwsze publikacje na ten temat (m.in. Edwarda Różyckiego) ukazały się jeszcze w okresie Polskiej Rzeczypospolitej Ludowej ${ }^{19}$. Wykorzystywane są również źródła drukowane, w tym opracowania oparte na materiałach już nieistniejących. Publikacje tego rodzaju rejestruje m.in. Bibliografia inwentarzy i katalogów księgozbiorów polskich i zatożonych $w$ Polsce do 1939 roku i Cathalogus cathalogorum. Inwentarze i katalogi

${ }^{14}$ Zob. m.in. M.J. LECH, Materiały do dziejów książi i czytelnictwa w okresie zaborów w archiwach polskich, Rocznik Biblioteki Narodowej (5) 1969, s. 23-57.

15 Np. J. GWIOŹDZIK, Źródła do dziejów książki w archiwach żeńskich klasztorów kontemplacyjnych XVI-XVIII w. Zarys problematyki, Biuletyn Bibliotek Kościelnych (1/2) 2009, s. 202-209.

16 Pod tym względem do pozytywnych wyjątków należy dokumentacja Biblioteki Publicznej m. st. Warszawy, zob. Archiwum Biblioteki Publicznej m. st. Warszawy. [T. 1] Akta nr 1-245. Oprac. Jadwiga Rudnicka, Janina Górka, Kazimiera Sokołowska-Grzeszczyk, Warszawa: Państwowe Wydawnictwo Naukowe 1977; [T. 2] Akta nr 246-595. Oprac. Kazimiera Sokołowska-Grzeszczyk, Warszawa: SBP 1993.

$17 \mathrm{Na}$ ten temat zob. Hanna ŁASKARZEWSKA, Założenia wstępne dotyczace „Informatora o polskich ksiegozbiorach historycznych i powstatych na ziemiach polskich do $1950 \mathrm{r}$.", [w:] Symposia bibliologica. Dokumentacja księgozbiorów historycznych, wspótpraca krajowa i międzynarodowa. Skutki II wojny światowej dla bibliotek polskich. Red. nauk. Andrzej Mężyński, Warszawa: Wydaw. DiG 1995, s. 19-40. Od 2014 r. PDKH zastąpiła Pracownia Historii Bibliotek i Czytelnictwa Instytutu Książki i Czytelnictwa BN.

18 Zob. m.in. Informator o polonikach w zbiorach rękopiśmiennych Lwowskiej Narodowej Naukowej Biblioteki Ukrainy im. Wasyla Stefanyka. Cz. 1. Zbiory Biblioteki Zaktadu Narodowego im. Ossolińskich zinwentaryzowane przed 1945 r. Oprac. Maciej Matwijów i Elżbieta Ostromęcka; Cz. 2. Zbiór Aleksandra Czołowskiego. Oprac. Konrad Rzemieniecki, Wrocław: Zakład Narod. im. Ossolińskich 2010-2015; Lidia KOWKIEL, Materiały do dziejów księgozbiorów prywatnych na Grodzieńszczyźnie w I połowie XIX wieku w archiwach, bibliotekach i muzeach Białorusi, Litwy i Polski, Białostocczyzna (1) 2000, s. 21-32; Biblioteki naukowe w Generalnym Gubernatorstwie w latach 1939-1945. Wybór dokumentów źródłowych. Oprac. Andrzej Mężyński, przy współpr. Hanny Łaskarzewskiej, Warszawa: LTW 2003.

19 E. RÓŻYCKI, Materiały źródłowe do dziejów polskiej książki w archiwach i bibliotekach Lwowa, Kijowa, Mińska i Wilna, Roczniki Biblioteczne (31) 1987, z. 2, s. 305-317.

Roczniki Biblioteczne 60, 2016

(C) for this edition by CNS 
bibliotek z ziem wschodnich Rzeczypospolitej od XVI wieku do 1939 roku autorstwa Urszuli Paszkiewicz ${ }^{20}$.

Opublikowano też wiele rozpraw metodologicznych i źródłoznawczych m.in. monografię Jacka Puchalskiego poświęconą źródłom do historii bibliotek, które przyczyniają się do wzbogacenia i udoskonalenia warsztatu badaczy ${ }^{21}$. Natomiast ciągle za mało jest edycji materiałów źródłowych ${ }^{22}$.

\section{OPRACOWANIA OGÓLNE}

W omawianym okresie ukazało się kilka publikacji polskich autorów syntetycznie przedstawiających dzieje powszechne książki i bibliotek, w tym ich przeszłość w Polsce. Podręcznik Józefa Grycza Historia bibliotek w zarysie (Warszawa 1949) i jego kolejne mutacje, zwłaszcza Historia ksiażki i bibliotek w zarysie (ostatnie wydanie 1972) w opracowaniu Alodii Kaweckiej-Gryczowej, służyły przez kilkadziesiąt lat kształceniu bibliotekarzy i popularyzacji tematyki. W połowie lat 70. ukazał się skrypt dla studentów bibliotekoznawstwa Henryka Dubo-

20 Urszula PASZKIEWICZ, Bibliografia inwentarzy i katalogów księgozbiorów polskich i założonych w Polsce do 1939 roku. Cz. 1. Księgozbiory instytucjonalne w układzie topograficznym, Warszawa: Wydaw. Uniwersytetu Warszawskiego 1990; eadem, Cz. 2. Księgozbiory prywatne w układzie abecadłowym nazwisk właścicieli, Warszawa: Wydaw. Uniwersytetu Warszawskiego 1990; eadem, Cathalogus cathalogorum. Inwentarze i katalogi bibliotek z ziem wschodnich Rzeczypospolitej od XVI wieku do 1939 roku. Spis scalony, poprawiony i uzupetniony. T. 1-2, Warszawa: Ministerstwo Kultury i Dziedzictwa Narodowego 2015.

21 J. PUCHALSKI, Źródła do historii bibliotek w Polsce w latach 1918-1947. Studium bibliologiczne, Warszawa: SBP 2007. Wśród autorów wypowiadających się na temat źródeł i metodologii badań nad historią księgozbiorów, bibliotek i bibliotekarstwa byli m.in. Karol Głombiowski, Krzysztof Migoń, Józef Skoczek, Renata Żurkowa, Marian J. Lech, Wiesław Bieńkowski, Kazimiera Maleczyńska, Jadwiga Kołodziejska, Barbara Bieńkowska, Jerzy Włodarczyk, Andrzej Kłossowski, Edward Potkowski, Jan Pirożyński, Krystyna Bednarska-Ruszajowa, Maria Kocójowa, Elżbieta Słodkowska, Tadeusz Zarzębski, Edward Różycki, Józef Wojakowski, Jerzy Plis, Irena Socha, Paulina Buchwald-Pelcowa, Maria Juda, Iwona Imańska, Anna Dymmel, Bożena Koredczuk, Anna Gruca, Iwona Pietrzkiewicz, Jolanta Gwioździk, Lidia Kowkiel, Jolanta Dzieniakowska i Ryszard Nowicki.

22 M.in. Korespondencja Józefa Andrzeja Załuskiego z lat 1724-1736. Oprac. Bogumił Stanisław Kupść, Krystyna Muszyńska, Wrocław: Zakład Narod. im. Ossolińskich 1967; Bibliotekarstwo polskie 1925-1951 w świetle korespondencji jego wspóttwórców. Oprac. Maria Dembowska, Warszawa: SBP 1995; Joanna PŁAZA, Bożena SAJNA, Pamiatki dziejów Biblioteki Załuskich, Warszawa: Biblioteka Narodowa 1997; K. BEDNARSKA-RUSZAJOWA, Biblioteki i ksiażki w pamiętnikach polskich XVII-XX wieku. Rekonesans źródłowy, Kraków: Wydaw. Uniwersytetu Jagiellońskiego 2003; Listy Józefa Maksymiliana Ossolińskiego do Ambrożego Grabowskiego (1813-1826). Oprac. Bogdan Horodyski, Kraków: Wydaw. Uniwersytetu Jagiellońskiego 2006; Powojenna ochrona zbiorów bibliotecznych w Polsce w latach 1944-1955. Wybór źródet. Oprac. Ryszard Nowicki, Bydgoszcz: Wydaw. Uniwersytetu Kazimierza Wielkiego 2013. 
wika $^{23}$, a w kolejnej dekadzie podręcznik Kazimiery Maleczyńskiej ${ }^{24}$ oraz zarys Barbary Bieńkowskiej i Haliny Chamerskiej ${ }^{25}$. Najnowsza publikacja tego typu — Książa na przestrzeni dziejów B. Bieńkowskiej ukazała się w 2005 roku $^{26}$. Pozycją poświęconą wyłącznie rodzimym dziejom kultury książki jest Tysiąc lat książki i bibliotek w Polsce B. Bieńkowskiej i H. Chamerskiej27.

Do powstania wymienionych opracowań przyczyniło się coraz obfitsze piśmiennictwo bibliologiczne i nie tylko, gdyż tematyka dziejów bibliotek pojawia się też $\mathrm{w}$ rozprawach m.in. z zakresu historii literatury, kultury, nauki, oświaty i kościołów. Dotyczy ono w nierównomiernym stopniu różnych okresów historycznych, regionów, subregionów i ośrodków lokalnych. Składa się z publikacji ujmujących historię bibliotek w obrębie dziejów książki bądź skupionych na typach bibliotek lub pojedynczych placówkach — o odmiennych tradycjach, wielkości i randze. Ich poziom jest bardzo zróżnicowany — od wątłych merytorycznie przyczynków, prac kronikarskich, recenzji (w większości sprawozdawczych ${ }^{28}$ ), haseł encyklopedycznych po obszerne monografie, artykuły monograficzne i problemowe, a także przyczynki oparte na badaniach źródłowych ${ }^{29}$.

Wiele prac przynależy do „zewnętrznej” — według określenia B. Bieńkowskiej $^{30}$ — warstwy badań nad księgozbiorami historycznymi, a więc analizujących okoliczności i uwarunkowania powstawania, funkcjonowania i roli bibliotek, bez pogłębionego rozbioru samych księgozbiorów. Uwagę zwraca również niedostatek kwantyfikacji zjawisk z przeszłości bibliotek, mimo istniejących możliwości

${ }^{23}$ H. DUBOWIK, Dzieje książki i bibliotek. Kompendium dla studentów bibliotekoznawstwa, Bydgoszcz: Wyższa Szkoła Pedagogiczna 1976.

24 K. MALECZYŃSKA, Historia książi i jej funkcji społecznej, Wrocław: Wydaw. Uniwersytetu Wrocławskiego 1987.

${ }^{25}$ B. BIEŃKOWSKA, H. CHAMERSKA, Zarys dziejów książki, Warszawa: Centrum Ustawicznego Kształcenia Bibliotekarzy 1987.

26 B. BIEŃKOWSKA, Ksiązka na przestrzeni dziejów. Przy współpr. Elżbiety Maruszak, Warszawa: Wydaw. Centrum Edukacji Bibliotekarskiej, Informacyjnej i Dokumentacyjnej im. Heleny Radlińskiej 2005.

27 B. BIEŃKOWSKA, H. CHAMERSKA, Tysiac lat ksiązki i bibliotek w Polsce, Wrocław: Zakład Narod. im. Ossolińskich 1992.

${ }^{28}$ Na słabość nurtu krytycznego w periodykach dziedzinowych zwracał uwagę m.in. Andrzej MĘŻYŃSKI, „Przegląd Biblioteczny” i jego recenzenci. Tylko nie tak, proszę!, Przegląd Biblioteczny 2008, z. 1, s. 7-12.

29 Zwłaszcza Encyklopedia wiedzy o książce. Red. nacz. Aleksander Birkenmajer, Bronisław Kocowski, Jan Trzynadlowski, red. gł. Alodia Kawecka-Gryczowa, Helena Więckowska, Stanisław Pazyra, Wrocław: Zakład Narod. im. Ossolińskich 1971; Encyklopedia współczesnego bibliotekarstwa polskiego. Red. Karol Głombiowski, Bolesław Świderski, Helena Więckowska, Wrocław: Zakład Narod. im. Ossolińskich 1976.

30 B. BIEŃKOWSKA, Inwentarze księgozbiorów prywatnych jako źródła do badań nad dziejami czytelnictwa, Studia o Książce (18) 1989, s. 65-76. 
w tym zakresie ${ }^{31}$. Niezbędny jest też rozwój studiów porównawczych ${ }^{32}$, także w ujęciu międzynarodowym, pozwalających na uchwycenie różnic i analogii między bibliotekarstwem w Polsce i w innych krajach oraz ich wzajemnego oddziaływania ${ }^{33}$. Wymagałoby to większego niż do tej pory zainteresowania historią bibliotekarstwa obcego ${ }^{34}$.

\section{OKRES OD ŚREDNIOWIECZA DO KOŃCA XVIII WIEKU}

Wśród opracowań ogólnych należy wymienić podręcznik Karola Głombiowskiego i Heleny Szwejkowskiej poświęcony książce rękopiśmiennej i bibliotece w starożytności i w średniowieczu ${ }^{35}$ oraz Anny Żbikowskiej-Migoń o dziejach książki w XVIII wieku ${ }^{36}$. K. Maleczyńska opublikowała zarys historii bibliotek XV-XVIII wieku ${ }^{37}$. Natomiast staropolską kulturę książki opisywały popularnonaukowe prace B. Bieńkowskiej ${ }^{38}$ i B. Kosmanowej ${ }^{39}$, a w ujęciu regionalnym m.in. Marii Barbary Topolskiej, która podjęła studia nad bibliotekami w Wielkim Księstwie Litewskim ${ }^{40}$.

${ }^{31} \mathrm{Z}$ dobrym rezultatem zastosował zestawienia liczbowe m.in. Jan WRÓBLEWSKI, Polskie biblioteki ludowe w zaborze pruskim i na terenie Rzeszy Niemieckiej w latach 1843-1939, Olsztyn: Ośrodek Badań Naukowych im. Wojciecha Kętrzyńskiego 1975.

${ }^{32}$ Zob. m.in. M. KOCÓJOWA, W poszukiwaniu modelu badań dziejów ośrodków książki polskiej, Roczniki Biblioteczne (27) 1983, z. 1/2, s. 375-407.

33 Zob. np. Marian ŁODYŃSKI, Zagadnienie „Biblioteki Narodowej” w Polsce i za granica, Przegląd Biblioteczny 1948, z. 1/2, s. 22-39; Jan KOZŁOWSKI, Biblioteka jako instytucja społeczeństwa preindustrialnego (XVII w.-I poł. XVIII w.), Rocznik Biblioteki Narodowej (27/28) 1994, s. 63-84; Anna TOKARSKA, Biblioteki nauczycielskie w XIX wieku na tle światowego bibliotekarstwa, Studia Bibliologiczne (12) 2000, s. 68-85.

${ }^{34}$ Zob. np. Janusz S. GRUCHAŁA, Iucunda familia librorum. Humaniści renesansowi w świecie książki, Kraków: Towarzystwo Autorów i Wydawców Prac Naukowych Universitas 2002.

35 K. GŁOMBIOWSKI, H. SZWEJKOWSKA, Ksią̇̇ka rękopiśmienna i biblioteka $w$ starożytności i średniowieczu, Warszawa: Państwowe Wydawnictwo Naukowe 1971 (kolejne wydania - 1980 i 1983).

36 Anna ŻBIKOWSKA-MIGOŃ, Dzieje książki i jej funkcji społecznej. Wiek XVIII, Wroclaw: Wydaw. Uniwersytetu Wrocławskiego 1987.

37 K. MALECZYŃSKA, Zarys historii bibliotek od XV do XVIII wieku. Skrypt dla studentów bibliotekoznawstwa, Wrocław: Wydaw. Uniwersytetu Wrocławskiego 1975 (2. wyd.- 1976).

38 B. BIEŃKOWSKA, Staropolski świat ksiązek, Wrocław: Zakład Narod. im. Ossolińskich 1976.

39 B. KOSMANOWA, Książka i jej czytelnicy w dawnej Polsce, Warszawa: Ludowa Spółdzielnia Wydawnicza 1981.

40 Maria BARBARA TOPOLSKA, Czytelnik i książka w Wielkim Księstwie Litewskim w dobie Renesansu i Baroku, Wrocław: Ossolineum 1984. Zob. też m.in. eadem, Biblioteki w Wielkim Księstwie Litewskim w XVI i pierwszej połowie XVII wieku, Pamiętnik Biblioteki Kórnickiej 1983, 
Do najważniejszych opracowań na temat historii bibliotek wieków średnich należą Zbiory rękopiśmienne w Polsce średniowiecznej (Warszawa 1947), autorstwa Marii Hornowskiej. Podstawą edycji był rękopis dostarczony przez Halinę Zdzitowiecką-Jasieńską. Publikacja nie charakteryzowała poszczególnych bibliotek, ich typów, funkcji i roli w kulturze, skupiała się natomiast na opisie kodeksów, głównie z klasztoru benedyktynów na Łysej Górze. W latach 80. XX wieku przypadkowo odnaleziono w archiwum BN notatki M. Hornowskiej uznane za zaginione w czasie wojny, a według Jerzego Kaliszuka zawierające opisy 700 manuskryptów „pochodzących z 12 księgozbiorów kościelnych (np. Wiślica, Beszowa) i zakonnych (benedyktyni: Święty Krzyż, Sieciechów; cystersi: Ląd, Paradyż, Koprzywnica, Sulejów; kanonicy regularni laterańscy: Mstów; bożogrobcy: Miechów)"41.

Charakterystykę bibliotek średniowiecznych zawiera natomiast wielokrotnie wznawiana Paleografia łacińska Władysława Semkowicza ${ }^{42}$. Ich dziejom w XIV-XV wieku w Polsce poświęcona jest monografia Jacka Wiesiołowskiego ${ }^{43}$ i rozprawy Edwarda Potkowskiego ${ }^{44}$. Wśród bibliotek katedralnych (kapitulnych) najlepiej rozpoznane zostały gnieźnieńska, krakowska, płocka i włocławska, m.in. dzięki studiom Adama Vetulaniego, Mariana Plezi, Mariana Rechowicza i Jadwigi Rył, a w ostatnich latach Kazimierza Rulki i Piotra Tafiłowskiego ${ }^{45}$. Badania nad

z. 20, s. 143-183; Marceli KOSMAN, Biblioteki w Wielkopolsce przedrozbiorowej, [w:] Biblioteki Wielkopolski. Red. nauk. Stanisław Kubiak, Poznań: Politechnika Poznańska 1983, s. 8-21.

${ }^{41}$ Jerzy KALISZUK, Średniowieczne rękopisy Biblioteki Narodowej utracone w czasie drugiej wojny światowej, [w:] Dziedzictwo utracone..., s. 247-260. Opierając się m.in. na odnalezionych materiałach M. Hornowskiej, J. Kaliszuk przekazał do druku Codices deperditi. Średniowieczne rękopisy tacińskie Biblioteki Narodowej utracone w czasie II wojny światowej, m.in. z wykazem 1446 rękopisów łacińskich.

${ }^{42}$ Władysław SEMKOWICZ, Paleografia łacińska. Wyd. 1, Kraków: Polska Akademia Umiejętności 1951; Wyd. 3, Kraków: Towarzystwo Autorów i Wydawców Prac Naukowych Universitas 2011, s. 136-178.

43 Jacek WIESIOŁOWSKI, Kolekcje historyczne w Polsce średniowiecznej XIV-XV wieku, Wrocław: Zakład Narod. im. Ossolińskich 1967.

${ }^{44}$ Np. E. POTKOWSKI, Książka rękopiśmienna w kulturze Polski średniowiecznej, Warszawa: Ludowa Spółdzielnia Wydawnicza 1984.

45 M.in.: Adam VETULANI, Krakowska biblioteka katedralna w świetle swego inwentarza z r. 1110, Slavia Antiqua (4) 1953, s. 163-192; idem, Średniowieczne rękopisy płockiej Biblioteki Katedralnej, Roczniki Biblioteczne (7) 1963 z. 3/4, s. 313-443; Marian PLEZIA, Księgozbiór Katedry Krakowskiej wedle inwentarza z r. 1110, Silva Rerum 1981, s. 16-29; Marian RECHOWICZ, Sztuki wyzwolone na przełomie XIV i XV wieku w świetle katalogów polskich bibliotek kapitulnych, Roczniki Teologiczno-Kanoniczne (19) 1972, z. 2, s. 57-67; Jadwiga RYŁ, Biblioteka Katedralna w Gnieźnie, Archiwa, Biblioteki i Muzea Kościelne (32) 1976, s. 159-248, (33) 1976, s. 237-97, (36) 1978, s. 211-265; eadem, Katalog rękopisów Biblioteki Katedralnej w Gnieźnie, Archiwa, Biblioteki i Muzea Kościelne (45) 1982, s. 5-201, (46) 1983, s. 5-150; Kazimierz RULKA, Średniowieczne księgi rękopiśmienne w Bibliotece Wyższego Seminarium Duchownego we Włocławku, Zapiski Kujawsko-Dobrzyńskie (15) 2001, s. 125-149; Piotr TAFIŁOWSKI, Biblioteki kapitut katedralnych w Gnieźnie i Poznaniu w XV i początkach XVI wieku, Archiwa, Biblioteki i Muzea Kościelne (102) 2014, s. 251-299. 
bibliotekami kolegiackimi i parafialnymi prowadzili m.in. Alfred Świerk, Marek Tomasz Zahajkiewicz i Józef Mandziuk ${ }^{46}$. Postępowały prace nad bibliotekami zakonnymi, w tym cystersów (m.in. studia Stanisława Rybandta, Andrzeja Wałkówskiego, Michała Brody ${ }^{47}$ ), benedyktynów (Marka Derwicha ${ }^{48}$ ), kanoników regularnych (Alfreda Świerka ${ }^{49}$ ), franciszkanów (Jerzego Kaliszuka ${ }^{50}$ ) i paulinów (Janusza Zbudniewka ${ }^{51}$ ). Natomiast na pełniejsze opracowanie czekają biblioteki zakonów żeńskich ${ }^{52}$. Średniowieczne dzieje książnicy jagiellońskiej odtworzył Jerzy Zathey ${ }^{53}$. Ukazały się też ważne prace na temat kultury książki późnego średniowiecza na dworach panujących (autorstwa m.in. Mieczysława Gębarowicza, Urszuli Borkowskiej ${ }^{54}$ ), mieszczan (Agnieszki Bartoszewicz ${ }^{55}$ ) i duchownych $\left(\right.$ Krzysztofa Brachy $\left.{ }^{56}\right)$.

46 M.in.: Alfred ŚWIERK, Średniowieczne rękopisy księgozbioru kościoła parafialnego w Lubinie Śl., Roczniki Biblioteczne (23) 1979, z. 2, s. 221-256; Marek T. ZAHAJKIEWICZ, Biblioteki kościelne w kulturze Polski średniowiecznej, Kościół w Polsce (4) 2005, s. 37-49; Józef MANDZIUK, Średniowieczne biblioteki kościelne na Śląsku, Kościół w Polsce (4) 2005, s. $145-173$.

47 Stanisław RYBANDT, Średniowieczne opactwo cystersów w Rudach, Wrocław: Zakład Narod. im. Ossolińskich 1977; idem, Katalog ksiag zachowanych z średniowiecznej biblioteki cystersów w Rudach, Warszawa: Instytut Wydawniczy PAX 1979; Andrzej WAŁKÓWSKI, Skryptorium klasztoru cystersów w Mogile do końca XIII wieku, Łódź: Wydaw. Wyższej Szkoły Edukacji Zdrowotnej 2009; Michał BRODA, Biblioteka klasztoru cystersów w Henrykowie do końca XV wieku, Kraków: Księgarnia Akademicka 2014.

48 Marek DERWICH, Benedyktyński Klasztor świętego Krzyża na Łysej Górze w średniowieczu, Warszawa, Wrocław: Wydaw. Naukowe PWN 1992.

49 M.in. A. ŚWIERK, Średniowieczna biblioteka klasztoru kanoników regularnych św. Augustyna w Żaganiu, Wrocław: Zakład Narod. im. Ossolińskich 1965.

50 J. KALISZUK, Spis książek klasztoru franciszkanów w Chetmnie z drugiej połowy XIII wieku, Studia Źródłoznawcze (47) 2009, s. 95-108.

51 Janusz ZBUDNIEWEK, Zbiór rękopisów paulińskich w Polsce, Z Badań nad Polskimi Księgozbiorami Historycznymi (12) 1992, s. 5-54.

52 M.in. Irena CZACHOROWSKA, Średniowieczne biblioteki klarysek ślaskich, [w:] Święta Klara z Asyżu w 800-lecie urodzin. Pod red. Stanisława Celestyna Napiórkowskiego, Wiesława Koca, Niepokalanów: Wydaw. Ojców Franciszkanów 1995, s. 199-211.

53 Jerzy ZATHEY, Biblioteka Jagiellońska w latach 1364-1492, [w:] Historia Biblioteki Jagiellońskiej. T. 1. 1364-1775, Jerzy Zathey, Anna Lewicka-Kamińska, Leszek Hajdukiewicz. Pod red. Ignacego Zarębskiego, Kraków: Uniwersytet Jagielloński 1966, s. 1-130.

54 Mieczysław GĘBAROWICZ, Psatterz floriański i jego geneza, Wrocław: Zakład Narod. im. Ossolińskich 1965; idem, Na śladach polskich bibliotek królewskich, Roczniki Biblioteczne (14) 1970, z. 1/2, s. 113-139; Urszula BORKOWSKA, Królewskie modlitewniki. Studium z kultury religijnej epoki Jagiellonów (XV i początek XVI wieku). Rozprawa habilitacyjna, Lublin: Redakcja Wydawnictw Katolickiego Uniwersytetu Lubelskiego 1988 (2. wyd. 1999).

55 Agnieszka BARTOSZEWICZ, Piśmienność mieszczańska w późnośredniowiecznej Polsce, Warszawa: Wydaw. Uniwersytetu Warszawskiego 2012.

56 Krzysztof BRACHA, Kolekcje kaznodziejskie w Polsce późnego średniowiecza, [w:] Średniowiecze w rozjaśnieniu. Pod red. Krzysztofa Skupieńskiego, Warszawa: Wydaw. DiG 2010, s. $27-50$.

Roczniki Biblioteczne 60, 2016

(C) for this edition by CNS 
Autorzy opracowań analizowali sposoby pomnażania księgozbiorów, pochodzenie dzieł $i$ ich znaczenie jako świadectwa czytelnictwa, komunikacji społecznej, strukturę tematyczną zbiorów i ich funkcje, w tym rolę piśmienności sakralnej i rozwój piśmienności pragmatycznej od XIII wieku jako elementu życia społecznego i indywidualnego średniowiecznych użytkowników książki. Nieliczne są odrębne, szczegółowe studia poświęcone budownictwu i wyposażeniu bibliotecznemu $^{57}$, organizacji ${ }^{58}$, opracowaniu i udostępnianiu zbiorów ${ }^{59}$. Pożądane są też badania porównawcze, np. w obrębie poszczególnych kategorii bibliotek, oraz pełniejsze analizy ich roli w obiegu i społecznej recepcji książki w średniowiecznej Polsce. Istnieje bowiem dysproporcja w stanie badań, wynikająca również z podstawy źródłowej, nad poszczególnymi regionami, miejscowościami, ośrodkami i środowiskami kultury książki. Istotne są też studia nad konsekwencjami pojawienia się od lat 70 . XV wieku druków w polskich zbiorach bibliotecznych ${ }^{60}$.

W powojennych studiach historyczno-bibliologicznych ważne miejsce zajęły rozważania nad rolą książki jako nośnika nowego prądu umysłowego, nieodzownego elementu warsztatu pracy twórczej i życia codziennego ludzi renesansu ${ }^{61}$. Przykładem mogą być monografie z lat 50-60. XX wieku, ówcześnie nowatorskie, mające niemałe walory metodologiczne: Anny Lewickiej-Kamińskiej o księgozbiorze Mikołaja Czepla, Leszka Hajdukiewicza o bibliotekach Macieja z Miechowa i Piotra Tomickiego, Stanisława Sokoła i Marii Pelczarowej o kolekcji Heyllów, Wacławy Szelińskiej o bibliotekach profesorów Uniwersytetu Krakowskiego ${ }^{62}$,

${ }^{57} \mathrm{~Np}$. Rafał WERSZLER, Rola armarii w kulturze i dziejach ksią̇ki, [w:] Regionalne dziedzictwo kulturowe jako baza dla ksztaltowania tożsamości lokalnych. Red. nauk. Samanta Kowalska, Poznań-Kalisz: Uniwersytet im. Adama Mickiewicza 2010, s. 168-198.

58 Np. Wiesław Franciszek MURAWIEC, Księgozbiory i książi rękopiśmienne w prawodawstwie ogólnym zakonu Braci Mniejszych w późnym średniowieczu, Folia Historica Cracoviensia (6) 1999, s. 49-61; Lidia PSZCZÓŁKOWSKA, Biblioteka przy kościele NP. Marii w Gdańsku ijej piętnastowieczny regulamin, Acta Universitatis Nicolai Copernici. Bibliologia (5) 2006, s. 75-87.

$59 \mathrm{~Np}$. Wojciech MROZOWICZ, O katalogach biblioteki franciszkanów zgorzelskich w średniowieczu, Roczniki Biblioteczne (45) 2001, s. 167-197.

${ }^{60}$ Zob. m.in. B. BIEŃKOWSKA, Staropolski świat..., s. 28; P. BUCHWALD-PELCOWA, Rola ksiażki w Polsce $w$ drugiej połowie XV wieku, [w:] eadem, Historia literatury i historia książki. Studia nad ksiązka i literatura od średniowiecza po wiek XVIII, Kraków: Towarzystwo Autorów i Wydawców Prac Naukowych Universitas 2005, s. 56; E. POTKOWSKI, Wielki przetom w dziejach komunikacji społecznej u progu epoki nowożytnej. Rękopis, książka ksylograficzna, druk, [w:] Przeszłość i teraźniejszość. Prace ofiarowane Profesorowi Adamowi Koseskiemu w siedemdziesiąta rocznicę urodzin. Red. Marian Dygo et al., Pułtusk: Akademia Humanistyczna im. Aleksandra Gieysztora 2009, s. 69-80.

${ }^{61}$ M.in. A. KAWECKA-GRYCZOWA, Miejsce ksiązki w kulturze polskiej XVI wieku, [w:] Polska w epoce odrodzenia. Państwo - spoleczeństwo - kultura. Pod red. Andrzeja Wyczańskiego, Warszawa: Wiedza Powszechna 1986, s. 441-443.

62 Anna LEWICKA-KAMIŃSKA, Renesansowy księgozbiór Mikołaja Czepla w Bibliotece Jagiellońskiej, Wrocław: Zakład Narod. im. Ossolińskich 1956; Leszek HAJDUKIEWICZ, Biblioteka Macieja z Miechowa, Wrocław: Zakład Narod. im. Ossolińskich 1960; idem, Księgozbiór 
a także rozprawy z dziejów czytelnictwa Karola Głombiowskiego i Krzysztofa Migonia $^{63}$. Wśród publikacji z ostatnich lat należy wymienić opracowanie Volsciany Andrzeja Obrębskiego ${ }^{64}$. Świat bibliotek XVI-XVIII wieku opisywały także rozprawy poświęcone kolekcjom dworskim. Czołowe miejsce wśród nich zajmuje Biblioteka ostatniego Jagiellona Alodii Kaweckiej-Gryczowej (Wrocław 1988). Należy wymienić też studia Jana Pirożyńskiego nad biblioteką księżnej brunszwickiej Zofii Jagiellonki ${ }^{65}$, Janusza Tondela nad zbiorami księcia pruskiego Albrechta Hohenzollerna i jego żony Anny Marii ${ }^{66}$ oraz opracowania popularnonaukowe Ireny Komasary o kolekcjach Jana III Sobieskiego i Wazów ${ }^{67}$. Wyczerpującego studium nie doczekała się natomiast warszawska biblioteka Stanisława Augusta Poniatowskiego ${ }^{68}$, mimo bogatej podstawy źródłowej ${ }^{69}$ i skatalogowania jej księgozbioru znajdującego się w Bibliotece Narodowej Ukrainy im. Wernad-

i zainteresowania bibliofilskie Piotra Tomickiego na tle jego działalności kulturalnej, Wrocław: Zakład Narod. im. Ossolińskich 1961; Stanisław SOKÓŁ, Maria PELCZAROWA, Księgozbiór gdańskich lekarzy Krzysztofa i Henryka Heyllów, Gdańsk: Biblioteka Gdańska PAN 1963; Wacława SZELIŃSKA, Biblioteki profesorów Uniwersytetu Krakowskiego w XV i początkach XVI wieku, Wrocław: Zakład Narod. im. Ossolińskich 1966.

${ }^{63}$ M.in. K. GŁOMBIOWSKI, Polska literatura polityczna na Śląsu od XVI do końca XVIII w. Studium z zakresu historii użytkowania ksiażki, Katowice: Śląsk 1960; K. MIGOŃ, Recepcja książki orientalistycznej na Śląsku do końca XVIII wieku, Wrocław: Zakład Narod. im. Ossolińskich 1969.

64 Andrzej OBRĘBSKI, Volsciana. Katalog renesansowego księgozbioru Piotra Dunin-Wolskiego, biskupa płockiego, Kraków: Księgarnia Akademicka 1999.

65 M.in. J. PIROŻYŃSKI, Księżna brunszwicka Zofia Jagiellonka (1522-1575) i jej biblioteka. Studium z dziejów kultury, Kraków: Uniwersytet Jagielloński 1986.

66 M.in. Janusz TONDEL, Biblioteka Zamkowa (1529-1568) księcia Albrechta Pruskiego w Królewcu, Toruń: Uniwersytet Mikołaja Kopernika 1992.

67 Irena KOMASARA, Jan III Sobieski - miłośnik ksiag, Wrocław: Ossolineum 1982; eadem, Książka na dworach Wazów w Polsce, Wrocław: Ossolineum 1994. Zob. też Edward RÓŻYCKI, Z dziejów zagrabionych polskich bibliotek królewskich. Biblioteka Jana III Sobieskiego w Rosyjskiej Bibliotece Narodowej w Sankt Petersburgu, [w:] Dziedzictwo utracone..., s. 385-417.

68 M.in. Jadwiga RUDNICKA, Wykorzystanie księgozbioru Stanisława Augusta, [w:] Z badań nad dawną książka. Studia ofiarowane prof. Alodii Kaweckiej-Gryczowej w 85-lecie urodzin. Red. Paulina Buchwald-Pelcowa, Warszawa: Biblioteka Narodowa 1993. T. 2, s. 555-574; Hanna ŁASKARZEWSKA, Biblioteka króla Stanisława Augusta Poniatowskiego, [w:] Historyczne księgozbiory warszawskie, Warszawa: Biblioteka Publiczna m. st. Warszawy. Biblioteka Główna 1995, s. 7-17; Alina DZIĘCIOŁ, Stanisław August Poniatowski i jego księgozbiór w świetle źródet zachowanych $w$ Bibliotece Narodowej Ukrainy w Kijowie, Kronika Zamkowa 2006 nr 1-2 (51-52), s. 109-121; Ewa MANIKOWSKA, Sztuka - ceremoniat - informacja. Studium wokót królewskich kolekcji Stanisława Augusta, Warszawa: Zamek Królewski 2007, s. 184-191. Zob. też J. WOJAKOWSKI, Biblioteka kozienicka Stanisława Augusta, Z Badań nad Polskimi Księgozbiorami Historycznymi (5) 1981, s. 99-137.

69 Biblioteka Stanisława Augusta na Zamku Warszawskim. Dokumenty. Oprac. Jadwiga Rudnicka, Wrocław: Zakład Narod. im. Ossolińskich 1988. 
skiego w Kijowie ${ }^{70}$. Rola książki i biblioteki w życiu elity władzy była przedmiotem rozważań ogólnych ${ }^{71}$ i badań szczegółowych, m.in. w monografiach bibliotek: Krzysztofa Opalińskiego ${ }^{72}$, Radziwiłłów ${ }^{73}$ oraz Izabeli Czartoryskiej ${ }^{74}$. Jednak zbyt mało jeszcze wiadomo o bibliotekach magnackich, tym bardziej o szlacheckich $^{75}$. Z pośród bibliotek wyższego duchowieństwa do najlepiej rozpoznanych należą kolekcje Jana Andrzeja Próchnickiego ${ }^{76}$ i Jana Leuderode ${ }^{77}$. Mniejszym zainteresowaniem badaczy cieszyły się księgozbiory duchowieństwa niższego, przy czym widoczny jest postęp w studiach nad kolekcjonerami śląskimi ${ }^{78}$. Natomiast wiele publikacji poświęcono bibliotekom mieszczańskim. Z braku miejsca wspomnę tylko znaczenie monografii K. Maleczyńskiej Z dziejów księgozbiorów mieszczańskich w Polsce 1506-1572 (Wrocław 1991) ${ }^{79}$, rozprawy Edwarda Różyckiego o kolekcjach lwowskich ${ }^{80}$, edycji źródłowych, np. Elżbiety Torój (księ-

70 H. ŁASKARZEWSKA, Pracownia Dokumentacji Księgozbiorów Historycznych, EBIB 2002, nr 10 (39), http://www.ebib.pl/2002/39/pdkh.php [dostęp: 3 IV 2016].

71 M.in. Władysław CZAPLIŃSKI, Józef DLUGOSZ, Życie codzienne magnaterii polskiej w XVII wieku, Warszawa: Państwowy Instytut Wydawniczy 1976, s. 151-163 (rozdział Magnat a książka); Anna KAMLER, Dariusz KUŹMINA, Uwagi o zainteresowaniach bibliofilskich szesnastowiecznej polskiej elity władzy, [w:] Historia memoria scriptorum. Ksiega Jubileuszowa z okazji osiemdziesięciolecia urodzin Profesora Edwarda Potkowskiego. Pod red. Jacka Krochmala, Warszawa: Naczelna Dyrekcja Archiwów Państwowych et al. 2015, s. 66-79.

72 Kamila SCHUSTER, Biblioteka Łukasza Opalińskiego marszałka nadwornego koronnego (1612-1662), Wrocław: Zakład Narod. im. Ossolińskich 1971.

73 Mariola JARCZYKOWA, Książka i literatura $w$ kręgu Radziwiłłów birżańskich w pierwszej połowie XVII wieku, Katowice: Wydaw. Uniwersytetu Śląskiego 1995; Wanda KARKUCIŃSKA, Anna z Sanguszków Radziwiłłowa (1676-1746). Działalność gospodarcza i mecenat, Warszawa: Wydaw. Semper 2000; eadem, Biblioteka i archiwum Radziwiłłów w Białej Podlaskiej, Z Badań nad Polskimi Księgozbiorami Historycznymi (16) 1995, s. 49-74. Zob. też m.in. Badania księgozbiorów Radziwiłłów. Materiały międzynarodowej sesji, Olsztyn, 6-7 października 1994 r. Red. Zoja Jaroszewicz-Pieresławcew, Warszawa: Wojciech Wójcicki 1995.

74 Zdzisław ŻYGULSKI, Dzieje zbiorów Puławskich (Świątynia Sybilli i Dom Gotycki), Kraków: [s.n] 1962; Barbara MIODOŃSKA, Katarzyna PŁONKA-BAŁUS, Puławska kolekcja rękopisów iluminowanych księżnej Izabeli Czartoryskiej, Kraków: Muzeum Narodowe 2001.

75 Zob. m.in. kilka artykułów z lat 1975-1984 Heleny BOGDANOW, w tym: Piśmiennictwo historyczne w ksiegozbiorach szlachty krakowskiej w XVIII wieku jako wyraz jej zainteresowań czytelniczych, Roczniki Biblioteczne (27) 1983, z. 1/2, s. 117-157; Księgozbiory szlacheckie XVI-XVII wieku. Kolekcje historyczne. T. 1-2, Warszawa: Wydaw. Uniwersytetu Warszawskiego 2004-2009.

76 Mieczysław GĘBAROWICZ, Jan Andrzej Próchnicki (1553-1633) mecenas i bibliofil. Szkic z dziejów kultury w epoce kontrreformacji, Kraków: Znak 1980.

77 Wacław URBAN, Jan Leuderode i jego księgozbiór z XVII wieku, Wrocław: Zgromadzenie Sióstr Św. Elżbiety 1981.

78 M.in. J. MANDZIUK, Biogramy śląskich bibliofilów duchownych z XVII wieku, Saeculum Christianum (11) 2004, nr 2, s. 245-272.

79 Zob. też K. MALECZYŃSKA, Zainteresowania czytelnicze mieszczan dolnośląskich okresu Renesansu, Wrocław: Wydaw. Uniwersytetu Wrocławskiego 1982.

80 E. RÓŻYCKI, Alembekowie i ich księgozbiory. Z dziejów kultury umysłowej mieszczaństwa lwowskiego okresu renesansu i baroku, Katowice: Wydaw. Uniwersytetu Śląskiego 2001.

Roczniki Biblioteczne 60, 2016

(C) for this edition by CNS 
gozbiory lubelskie) ${ }^{81}$, a także licznych artykułów Renaty Żurkowej (księgozbiory krakowskie) $^{82}$, Krystyny Podlaszewskiej i Iwony Imańskiej (m.in. księgozbiory gdańskie i elbląskie) ${ }^{83}$. Podjęto również badania nad księgozbiorami poznański$\mathrm{mi}^{84}$ i warszawskimi ${ }^{85}$. Odnośnie do kolekcji uczonych, literatów i artystów pominąwszy rozprawy z zakresu historii nauki, kultury, literatury, biografistyki pobocznie traktujące interesującą nas tematykę $e^{86}$ — należy wspomnieć o opracowaniach poświęconych bibliotece Mikołaja Kopernika ${ }^{87}$, Szymona Szymonowica $^{88}$ i Hieronima Pinocciego ${ }^{89}$. Zainteresowanie badaczy wzbudziły też m.in. księgozbiory Biernata z Lublina, Bartłomieja Keckermanna, Jana Innocentego Petrycego, Stanisława Lubienieckiego i Jana Brożka ${ }^{90}$. Dzięki studiom Ryszarda

Zob. też idem, Książka polska i księgozbiory we Lwowie w epoce renesansu i baroku, Wrocław: Ossolineum 1994.

81 Elżbieta TORÓJ, Inwentarze księgozbiorów mieszczan lubelskich z lat 1591-1678, Lublin: Wydaw. Uniwersytetu Marii Curie-Skłodowskiej 1997.

${ }^{82}$ M.in. R. ŻURKOWA, Księgozbiory mieszczan krakowskich w XVII wieku, Rocznik Biblioteki Polskiej Akademii Nauk w Krakowie (13) 1967, s. 21-51.

83 M.in. Krystyna PODLASZEWSKA, Księgozbiory mieszczan gdańskich w XVIII wieku, Zapiski Historyczne (35) 1970, z. 1, s. 51-63; eadem, Prywatne biblioteki mieszczan elblaskich w XVI i pierwszej połowie XVII wieku, Studia o Bibliotekach i Zbiorach Polskich (5) 1993, s. 47-69; I. IMAŃSKA, W'́ród bibliofilów elbląskich z połowy XVIII wieku, Studia o Bibliotekach i Zbiorach Polskich (1) 1991, s. 19-28.

${ }^{84}$ M.in. Inwentarze mieszczańskie z lat 1528-1635 z ksiag miejskich Poznania. Oprac. Stanisław Nawrocki i Jerzy Wisłocki, Poznań: Państwowe Wydawnictwo Naukowe Oddział w Poznaniu 1961; Maria KRAMPEROWA, Witold MAISEL, Księgozbiory mieszczan poznańskich z drugiej połowy XVI w., Studia i Materiały z Dziejów Wielkopolski i Pomorza (6) 1960, z. 1, s. 257-308.

85 M.in. Jadwiga RUDNICKA, Biblioteki mieszczan warszawskich za Stanistawa Augusta, [w:] Warszawa XVIII wieku. Z. 2. Red. nauk. Jerzy Kowecki, Warszawa: PWN 1973, s. 125-160.

86 Dzieje książki zajmują ważne miejsce np. w publikacji Henryka BARYCZA, Z epoki renesansu, reformacji i baroku. Prądy, idee, ludzie, książki, Warszawa: Państwowy Instytut Wydawniczy 1971.

87 Paweł CZARTORYSKI, The Library of Copernicus, Studia Copernicana (16) 1978, s. 355-398. Zob. też m.in. Leonard JASTRZĘBOWSKI, Biblioteka Mikołaja Kopernika, Toruń: Państwowe Wydawnictwo Naukowe. Oddział 1971; Grażyna ROSIŃSKA, Krakowski księgozbiór Mikołaja Kopernika w kodeksach ,Copernicana 4" i ,Copernicana 6” Biblioteki Uniwersyteckiej w Uppsali, Res Historica (13) 2002, s. 105-123.

88 Wanda SZWARCÓWNA, Biblioteka Szymona Szymonowica, Lublin: Wojewódzka Biblioteka Publiczna 1989.

89 Karolina TARGOSZ, Hieronim Pinocci. Studium z dziejów kultury naukowej w Polsce w XVII wieku, Wrocław: Zakład Narod. im. Ossolińskich 1967.

90 M.in. Stanisław GRZESZCZUK, O notatkach autobiograficznych, lekturach i bibliotece Biernata z Lublina, Biuletyn Biblioteki Jagiellońskiej (38) 1988, nr 1/2, s. 31-62; Beata GRYZIO, Księgozbiór Bartłomieja Keckermanna, Rocznik Biblioteki Narodowej (39/40) 2008, s. 225-244; Renata ŻURKOWA, Z dziejów biblioteki Jana Innocentego Petrycego, Rocznik Biblioteki Polskiej Akademii Nauk w Krakowie (14) 1968, s. 43-63; Janusz TAZBIR, Księgozbiór Stanisława Lubienieckiego, Rocznik Biblioteki Narodowej (4) 1968, s. 197-233; Leszek HAJDUKIEWICZ, Nieznany inwentarz instrumentarium i biblioteki Jana Brożka, Studia i Materiały z Dziejów Nauki Polskiej Seria A (12) 1968, s. 303-325. 
Kazimierza Lewańskiego (1995-1996) poznaliśmy zarys dziejów i zachowane książki z Biblioteki Nacji Polskiej (Bibliotheca nationis Polonae) funkcjonującej na Uniwersytecie Padewskim od końca XVI do lat 60. XVIII wieku ${ }^{91}$.

Do znaczącego dorobku należą kolejne opracowania dziejów bibliotek klasztornych. Prace zbiorowe, monografie i ogólne artykuły poświęcono m.in. bibliotekom cystersów ${ }^{92}$, franciszkanów ${ }^{93}$, karmelitów ${ }^{94}$, bazylianów ${ }^{95}$, dominikanów ${ }^{96}$, kartuzów $^{97}$, kanoników regularnych ${ }^{98}$, bernardynów ${ }^{99}$, jezuitów ${ }^{100}$, oraz bene-

91 Ryszard Kazimierz LEWAŃSKI, Bibliotheca Nationis Polonae na Uniwersytecie Padewskim (Cz. 1), Ofiarodawcy ksiązek dla Biblioteki Nacji Polskiej w Padwie (Cz. 2), Biuletyn Biblioteki Jagiellońskiej (45) 1995, s. 63-83 i (46) 1996, s. 143-214.

92 M.in. Biblioteki i skryptoria cysterskie na Pomorzu. Pelplin 23-25 maja 2008. Red. Alicja Słyszewska, Anastazy Nadolny, Andrzej Wałkówski, Pelplin: Wydaw. Bernardinum 2010.

93 Na czele z książką Karola Głombiowskiego, Biblioteka franciszkanów w Nysie w świetle inwentarza z roku 1678, Wrocław: Biblioteka Uniwersytecka 1953. Zob. też m.in. K. ZAWADZKA, Problem bibliotek franciszkańskich na Śląsku (1236-1810), [w:] Franciszkanie w Polsce średniowiecznej. Cz. 2-3. Franciszkanie na ziemiach polskich. Red. tomu Urszula Borkowska et al., Kraków: Prowincjałat OO. Franciszkanów Konwentualnych Prowincji św. Antoniego i bł. Jakuba Strepy 1989, s. 137-158.

94 Józef DŁUGOSZ, Biblioteka klasztoru karmelitów bosych w Wiśniczu (1630-1649), Archiwa, Biblioteki i Muzea Kościelne (13) 1966, s. 91-169; Szymon SUŁECKI, Księgozbiór klasztoru karmelitów na Piasku w Krakowie, Kraków: Wydaw. Avalon 2014.

95 Maria PIDŁYPCZAK-MAJEROWICZ, Bazylianie w Koronie i na Litwie. Szkoły i książki $w$ działalności zakonu, Warszawa: Państwowe Wydawnictwo Naukowe 1986; eadem, Biblioteki i bibliotekarstwo zakonne na wschodnich ziemiach Rzeczpospolitej w XVII-XVIII wieku, Wrocław: Wydaw. Uniwersytetu Wrocławskiego 1996.

96 K. ZAWADZKA, Biblioteki klasztorne dominikanów na Ślasku (1239-1810), Acta Universitatis Wratislaviensis Bibliothecalia Wratislaviensia (5) 1999, s. 3-128. Zob. też m.in. Tomasz STOLARCZYK, Analecta Dominiciana. Szkice z dziejów Zakonu Braci Kaznodziejów w Polsce środkowej (XIII-XVIII wiek), Wieluń: Wieluńskie Towarzystwo Naukowe 2016, s. 197-208 (rozdział Biblioteki dominikańskie w średniowiecznej Polsce i Rzeczypospolitej Obojga Narodów. Aktualny stan badań $i$ dalsze potrzeby).

97 Krzysztof NIERZWICKI, Biblioteki Kartuzji Kaszubskiej oraz jej konwentów filialnych w Berezie Kartuskiej i Gidlach, Pelplin: Bernardinum 2001.

98 Ewa ZIELIŃSKA, Kultura intelektualna kanoników regularnych z klasztoru w Kraśniku w latach 1469-1563, Lublin: Wydaw. Uniwersytetu Marii Curie-Skłodowskiej 2002; Kazimierz ŁATAK, Ze studiów nad kulturą umysłową kanoników regularnych krakowskiej prepozytury Bożego Ciała w XV i XVI wieku, Kraków: Zakon Kanoników Regularnych Laterańskich 2009. Zob. też m.in. Klara ANTOSIEWICZ, Biblioteki zakonu Ducha Świętego w Polsce, Archiwa, Biblioteki i Muzea Kościelne (41) 1980, s. 351-400, (42) 1981, s. 151-183.

99 Zbigniew LARENDOWICZ, Biblioteka Klasztoru Ojców Bernardynów w Leżajsku, Kraków: Wydaw. OO. Bernardynów Calvarianum 2007. Zob. też m.in. Emilian LENART, Biblioteki bernardyńskie w Polsce od 2 pot. XV do końca XVIII wieku, [w:] Pięćset pięćdziesiąt lat obecności oo. Bernardynów w Polsce (1453-2003). Pod red. Wiesława F. Murawca, Damiana A. Muskusa, Kalwaria Zebrzydowska-Kraków: Wydaw. OO. Bernardynów Calvarianum 2006, s. 659-677.

100 Ludwik GRZEBIEŃ, Organizacja bibliotek jezuickich w Polsce od XVI do XVIII wieku. Wyd. 2 uzup., Kraków: Wydaw. WAM 2013.

Roczniki Biblioteczne 60, 2016

(C) for this edition by CNS 
dyktynów ${ }^{101}$, paulinów ${ }^{102}$ i pijarów ${ }^{103}$. Rzadziej zajmowano się bibliotekami zakonów żeńskich ${ }^{104}$, lecz całościowo ujęła tę problematykę Jolanta Gwioździk ${ }^{105}$. Spośród bibliotek kościelnych szersze opracowania mają katedralne (kapitulne) w Gnieźnie ${ }^{106}$, Łowiczu ${ }^{107}$, Płocku ${ }^{108}$ oraz we Fromborku ${ }^{109}$ i w Wilnie ${ }^{110}$, a także kolegiackie w Sandomierzu ${ }^{111}$, Wiślicy ${ }^{112}$ i Kielcach ${ }^{113}$. Badaniom nad bibliotekami parafialnymi z XVI-XVIII wieku nadał w połowie lat 50. ubiegłego wieku impuls artykuł Hieronima Eugeniusza Wyczawskiego ${ }^{114}$. Zaowocowały one m.in. monografiami Krzysztofa Macieja Kowalskiego, Tomasza Moskala i Joanny Szady ${ }^{115}$. Ważne są też studia, zwłaszcza Józefa Trypućki, nad bibliotekami zrabo-

101 M.in. W. MROZOWICZ, Ksiązka i biblioteka benedyktyńska w społeczeństwie Polski średniowiecznej i nowożytnej, [w:] Klasztor w społeczeństwie średniowiecznym i nowożytnym. Red. Marek Derwich, Anna Pobóg-Lenartowicz, Opole: Pracownia Badań nad Dziejami Zakonów i Kongregacji Kościelnych 1996, s. 223-232.

102 M.in. J. ZBUDNIEWEK, Kodeks Regut Paulińskich zwany „Katenatem” na tle kultury książki w zakonie paulinów w XVI stuleciu, Z Badań nad Polskimi Księgozbiorami Historycznymi (4) 1980, s. 107-134.

103 M.in. Ryszard MĄCZYŃSKI, Warszawskie biblioteki księży pijarów, Rocznik Historii Sztuki (21) 1997, s. 91-139.

104 M.in. H. SZWEJKOWSKA, Biblioteka klasztoru cystersek w Trzebnicy, Wrocław: Państwowe Wydawnictwo Naukowe 1955.

105 J. GWIOŹDZIK, Kultura pisma i książi w żeńskich klasztorach dawnej Rzeczypospolitej XVI-XVIII wieku, Katowice: Wydaw. Uniwersytetu Śląskiego 2015. Zob. też m.in. eadem, Biblioteka panien benedyktynek tacińskich we Lwowie (XVI-XVIII wiek), Katowice: Wydaw. Uniwersytetu Śląskiego 2001.

106 J. RYŁ, Biblioteka Katedralna...

107 M.in.: Stanisław LIBROWSKI, Wypisy z akt kapituly w Łowiczu do zakrystii, skarbca, biblioteki, archiwum i kancelarii miejscowej kolegiaty i kapituły z lat 1525-1818, Archiwa, Biblioteki i Muzea Kościelne (52) 1986, s. 257-400; (53) 1986, s. 275-393; (54) 1987, s. 299-404.

108 Waldemar GRACZYK, Biblioteka katedralna Płocka od średniowiecza do nowożytności, [w:] Biblioteka Wyższego Seminarium Duchownego w Płocku. Red. Waldemar Graczyk, Płock: Płocki Instytut Wydawniczy 2003, s. 7-71.

109 M.in. Halina KEFERSTEIN, Biblioteka kapituty fromborskiej, Rocznik Olsztyński (12/13) 1981, s. 49-69.

110 Wioletta PAWLIKOWSKA-BUTTERWICK, Księgozbiór biblioteki katedralnej w Wilnie z końca XVI w., Odrodzenie i Reformacja w Polsce (56) 2012, s. 161-190.

111 M.in.: Tomasz MOSKAL, Ksią̇ka w kulturze sandomierskiego środowiska kolegiackiego do 1818 roku, Lublin: Wydaw. Katolickiego Uniwersytetu Lubelskiego 2013.

112 Piotr KARDYŚ, Biblioteka przykolegiacka w Wiślicy (XV-XVII wiek), Archiwa, Biblioteki i Muzea Kościelne (82) 2004, s. 85-102.

113 Andrzej KWAŚNIEWSKI, Księgozbiór Kapituly Kieleckiej w świetle inwentarza z 1598 r., Archiwa, Biblioteki i Muzea Kościelne (99) 2013, s. 43-92.

114 Hieronim E. WYCZAWSKI, Biblioteki parafialne $w$ diecezji krakowskiej u schytku XVI wieku, Polonia Sacra (6) 1953/54, z. 2/4, s. 114-142; (7) 1955, z. 1, s. 27-68; z. 2/3, s. 159-173.

115 Krzysztof Maciej KOWALSKI, Ksiegozbiory parafialne archidiakonatu pomorskiego w XVI-XVIII w. Studium z dziejów kultury intelektualnej Prus Królewskich, Gdańsk: Uniwersytet Gdański 1993; T. MOSKAL, Biblioteki parafialne $w$ archidiakonacie sandomierskim $w$ XVIII wie$k u$, Sandomierz: Wydaw. Diecezjalne 2005; Janna SZADY, Ksiegozbiory parafialne w prepozytu- 
wanymi przez Szwedów w XVII-XVIII wieku ${ }^{116}$. Natomiast zbyt mało jeszcze wiemy o bibliotekach różnowierczych ${ }^{117}$.

Historię Biblioteki Jagiellońskiej za lata 1492-1655 w opracowaniu A. Lewickiej-Kamińskiej uzupełnił L. Hajdukiewicz, charakteryzując okres kryzysu i oczekiwania na reformę Akademii i jej książnicy w latach $1655-1775^{118}$. Znajomość bibliotekarstwa polskiego w XVIII wieku pogłębiły też prace o Bibliotece Załuskich. Już w 1948 roku Edward Kuntze „,elowo, nawiązując do przedwojennych czasów" "119, aby zamanifestować ciągłość bibliotekarstwa polskiego w zmienionych warunkach ustrojowych, poświęcił zeszyt „Przeglądu Bibliotecznego” właśnie Bibliotece Rzeczypospolitej, zamieszczając w nim m.in. artykuły Piotra Bańkowskiego i Mariana Łodyńskiego ${ }^{120}$. Problematyka ta znalazła kontynuację w pracach Bogumiła Stanisława Kupścia, Jana Kozłowskiego, Tadeusza Zarzębskiego, Zdzisława Libery, Elżbiety Gondek i innych badaczy ${ }^{121}$. Dzieje bibliotek

rze wiślickiej w II połowie XVIII wieku, Lublin: Towarzystwo Naukowe Katolickiego Uniwersytetu Lubelskiego 2008.

116 M.in. Czesław PILICHOWSKI, Z dziejów szwedzkich zaborów bibliotek i archiwów polskich w XVII i XVIII wieku, Gdańsk: Gdańskie Towarzystwo Naukowe 1960; Jakub Zdzisław LICHAŃSKI, Księgozbiór Kolegium Jezuitów w Braniewie. Dzieje i charakterystyka, [w:] J. TRYPUĆKO, op. cit. Vol. 1, s. 69-96; Maria JUDA, Ewa TEODOROWICZ-HELLMAN, Polonika $w$ bibliotece katedralnej $w$ Strängnäs $=$ The polonica in the Library of Strängnäs Cathedral. In cooperation with Ragnhild Lundgren, Stockholm: Stockholm University Departament of Slavic Languages and Literatures 2011.

117 M.in. Wojciech KRIEGSEISEN, Książka i biblioteki w kulturze ewangelików polskich w XVII i XVIII, Z Badań nad Polskimi Księgozbiorami Historycznymi (13) 1991, s. 5-40; Jakub NIEDŹWIEDŹ, Kultura literacka Wilna (1323-1655). Retoryczna organizacja miasta, Kraków: Wydaw. Universitas 2012, s. 81-122.

118 A. LEWICKA-KAMIŃSKA, Biblioteka Jagiellońska w latach 1492-1655, [w:] Historia Biblioteki Jagiellońskiej, s. 131-271; L. HAJDUKIEWICZ, Biblioteka Jagiellońska w latach 1655-1775, [w:] Historia Biblioteki Jagiellońskiej, s. 275-426.

119 List Edwarda Kuntzego do Józefa Grycza z 12 maja 1947 r., Dział Zbiorów Specjalnych BN, sygn. akc. 14966, t. 3 b.

120 Piotr BAŃKOWSKI, Andrzej Załuski i jego dzieło ( $w$ dwóchsetna rocznice otwarcia Biblioteki Załuskich w Warszawie), Przegląd Biblioteczny 1948, z. 1/2, s. 1-21. Zob. też idem, Biblioteka Publiczna Zaluskich i jej twórcy, Warszawa: SBP 1959; M. ŁODYŃSKI, Zagadnienie „Biblioteki Narodowej” w Polsce i za granica, Przegląd Biblioteczny 1948, z. 1/2, s. 22-39. Zob. też idem, Biblioteka Rzplitej — Załuskich zwana na tle ówczesnych bibliotek zagranicznych, [w:] Z dziejów ksiązki i bibliotek w Warszawie. Wydawnictwo jubileuszowe z okazji 50-lecia Biblioteki Publicznej m. st. Warszawy. Praca zbiorowa pod red. Stanisława Tazbira, Warszawa: Państwowy Instytut Wydawniczy 1961, s. 11-50.

121 M.in. B.S. KUPŚĆ, Z dziejów fundacji Biblioteki Załuskich, Rocznik Biblioteki Narodowej (1) 1965, s. 258-292; J. KOZŁOWSKI, Szkice o dziejach Biblioteki Załuskich, Wrocław: Zakład Narod. im. Ossolińskich 1986; Tadeusz ZARZĘBSKI, Biblioteka Rzeczypospolitej, Warszawa: Biblioteka Narodowa 1997; Zdzisław LIBERA, Narodziny idei Biblioteki Narodowej w kulturze polskiego Oświecenia, Warszawa: Biblioteka Narodowa 2003; Elżbieta GONDEK, Józefa Andrzeja Załuskiego dzieło bibliograficzne i bibliofilskie, Katowice: Wydaw. Gnome 2005; Bracia Załuscy - ich epoka i dzieło. Zbiór studiów pod red. nauk. Doroty Dukwicz, Warszawa: Biblioteka Narodowa 2011. 
różnych typów w latach 1740-1830 przedstawiła w skrócie Krystyna Bednarska-Ruszajowa w syntezie poświęconej książce w okresie polskiego oświecenia ${ }^{122}$. Najlepiej rozpoznany został okres stanisławowski, zwłaszcza w kontekście polityki i działalności bibliotecznej Komisji Edukacji Narodowej ${ }^{123}$. Przedmiotem dociekań były ponadto: kształtowanie się idei biblioteki publicznej i rozwój wiedzy o bibliotekach (głównie w pracach Anny Żbikowskiej-Migoń ${ }^{124}$ ), funkcje oświeceniowego piśmiennictwa w księgozbiorach (Jadwiga Rudnicka; Józef Wojakowski i in.) ${ }^{125}$ oraz gabinety i wypożyczalnie książek (Józef Szczepaniec ${ }^{126}$ ). Zajmowano się także lokalami i wyposażeniem bibliotek ${ }^{127}$, ochroną i konserwacją zbiorów ${ }^{128}$, procesami bibliotecznymi i bibliotekarzami ${ }^{129}$.

122 K. BEDNARSKA-RUSZAJOWA, Uczyć, bawić, wychowywać. Książa i jej funkcja spoteczna w Polsce w okresie Oświecenia, Kraków: Oficyna Wydawnicza Impuls 2004, s. 158-189.

123 M.in. M. ŁODYŃSKI, Z dziejów organizacji nauki w Polsce. Początki polskiej polityki bibliotecznej (1774-1794), Przegląd Zachodni (9) 1953, t. 1, s. 606-613; Jadwiga RUDNICKA, Książka w działalności Komisji Edukacji Narodowej, Przegląd Biblioteczny (41) 1973, z. 4, s. $409-420$.

124 M.in. A. ŻBIKOWSKA-MIGOŃ, Od księgozbioru prywatnego do biblioteki publicznej: XVIII-wieczne programy i realizacje, [w:] Ks. Leopold Jan Szersznik znany i nieznany. Materiaty z konferencji naukowej, Cieszyn, 6-7 listopada 1997. Red. Anežka Bad'urová i Hanna Łaskarzewska, Cieszyn: Książnica Cieszyńska 1998, s. 7-18; eadem, Historia książki w XVIII wieku. Początki bibliologii, Warszawa: Państwowe Wydawnictwo Naukowe 1989, s. 185-226.

125 J. RUDNICKA, Biblioteka Ignacego Potockiego, Wrocław: Zakład Narod. im. Ossolińskich 1953; Nowożytna myśl naukowa w szkołach i księgozbiorach polskiego oświecenia. Pod red. Ireny Stasiewicz-Jasiukowej, Wrocław: Zakład Narod. im. Ossolińskich 1976; J. WOJAKOWSKI, Biblioteka Królewskiego Korpusu Kadetów w Warszawie, Warszawa: Wydaw. Uniwersytetu Warszawskiego 1989. Zob. też m.in. Zofia SINKO, Powieść zachodnioeuropejska w Polsce stanisławowskiej na podstawie inwentarzy bibliotecznych i katalogów, Pamiętnik Literacki (57) 1966, z. 4, s. 581-624; Wacław OLSZEWICZ, Z dziejów bibliotek i miłośnictwa książek w Polsce w XVIII w., Roczniki Biblioteczne (12) 1968, s. 51-96; Stefan ROSOŁOWSKI, Książka i biblioteka $w$ procesie kształcenia wojskowego w Polsce w okresie Oświecenia, Roczniki Biblioteczne (14) 1970, s. 537-674; A. ŻBIKOWSKA-MIGOŃ, Książka naukowa w kulturze polskiego Oświecenia, Wrocław: Państwowe Wydawnictwo Naukowe 1977, s. 124-151; Tadeusz BIEŃKOWSKI, Książki szkolne w Polsce od XVI do połowy XVIII wieku, Studia o Książce (8) 1978, s. 43-50; Wojciech GRZELECKI, Książki szkolne i biblioteki szkól-kolonii akademickich Uniwersytetu Krakowskiego (1588-1773), Z Badań nad Polskimi Księgozbiorami Historycznymi (9) 1986, s. 181-198.

126 Józef SZCZEPANIEC, Gabinety $i$ wypożyczalnie literatury w Polsce w drugiej połowie XVIII w., Ze Skarbca Kultury (29) 1983 z. 37, s. 7-108.

127 Konrad ZAWADZKI, Dzieje gmachu Biblioteki Zaluskich, Warszawa: Towarzystwo Przyjaciół Książki [1970]. Zob. też m.in. J. RUDNICKA, Budowa biblioteki Stanisława Augusta, Roczniki Biblioteczne (29) 1985, z. 1/2, s. 289-297.

128 Janisław OSIĘGŁOWSKI, Konserwacja książki w Polsce przedrozbiorowej, Poznań: Wydaw. Naukowe Uniwersytetu im. Adama Mickiewicza w Poznaniu 1985. Zob. też m.in. Edward RÓŻYCKI, Stan zachowania i konserwacja książi w województwie ruskim, [w:] Z życia książki. Ochrona i konserwacja zbiorów bibliotecznych oraz konteksty. Prace dedykowane profesorowi Leonardowi Ogiermanowi. Pod redakcją Anny Tokarskiej, Katowice: Wydaw. Uniwersytetu Śląskiego 2015, s. 109-125.

129 M.in. J. SZCZEPANIEC, Obowiazkowy egzemplarz biblioteczny $w$ Polsce $w$ drugiej połowie XVIII w., Rocznik Zakładu Narodowego im. Ossolińskich (5) 1957, s. 381-390; Maria 
Znaczenie upadku Rzeczypospolitej dla polskiego bibliotekarstwa oczywiście odzwierciedliło się w powojennym piśmiennictwie, m.in. w rozważaniach nad trwałością idei biblioteki narodowej w okresie zaborów, w badaniach nad krajowymi i emigracyjnymi przedsięwzięciami tworzenia zasobu piśmiennictwa polskiego ${ }^{130}$. Przełom XVIII/XIX wieku (i następne dziesięciolecia) przyniósł też likwidację wielu bibliotek zakonnych ${ }^{131}$. Ponieważ do rozbiorów biblioteki te dominowały w Polsce, a ich kolekcje (nie wszystkie i nie w całości) zasiliły polskie biblioteki, ich los należy zatem rozpatrywać także w kontekście narodzin nowoczesnego bibliotekarstwa polskiego ${ }^{132}$.

\section{XIX-XX WIEK}

Całościowe ujęcie historii „stulecia bibliotek” ${ }^{\text {133 }}$ stanowi popularnonaukowa praca K. Maleczyńskiej Książki i biblioteki w Polsce okresu zaborów (Wrocław 1987) $)^{134}$. Problematyka wpływu wytycznych KEN na politykę biblioteczną w Księstwie Warszawskim i Królestwie Polskim była przedmiotem studiów M. Łodyńskiego ${ }^{135}$, a T. Zarzębski scharakteryzował stosunek zaborców do

SIPAYŁŁO, Fata libellorum, Rocznik Biblioteki Narodowej (4) 1968, s. 253-264; Barbara GERLICH, Bibliotekarze Polski przedrozbiorowej, Roczniki Biblioteczne (23) 1979, z. 1, s. 107-129; eadem (GERLICH-PARTEL), Udostępnianie zbiorów w bibliotekach Rzeczypospolitej XVII-XVIII wieku, Roczniki Biblioteczne (29) 1985, z. 1/2, s. 243-262.

130 M.in. E. SŁODKOWSKA, Idea biblioteki narodowej w okresie zaborów (1795-1917), [w:] 50 lat Biblioteki Narodowej, Warszawa 1928-1978. Red. Witold Stankiewicz, Warszawa: Biblioteka Narodowa 1984, s. 27-48.

131 M.in. Kasaty klasztorów na obszarze dawnej Rzeczypospolitej Obojga Narodów i na Śląsku na tle procesów sekularyzacyjnych w Europie. T. 3. Źródła. Skutki kasat XVIII i XIX w. Kasata w latach 1954-1956. Red. Marek Derwich, Wrocław: Pracownia Badań nad Dziejami Zakonów i Kongregacji Kościelnych 2014; Tomasz CIESIELSKI, Książki poddane w 1841 r. cenzurze prewencyjnej. Przyczynek źródłowy do dziejów bibliotek klasztorów skasowanych na mocy ukazu z 1832 r. w guberniach zachodnich Imperium Rosyjskiego, Hereditas Monasteriorum (4) 2014, s. $235-259$.

132 K. MIGOŃ, Kasaty klasztorów w XVIII $i$ XIX w. a narodziny nowoczesnego bibliotekarstwa, [w:] Bibliotheca Lindiana. Samuel Bogumit Linde (1771-1847) pierwszy dyrektor Biblioteki Uniwersyteckiej $w$ Warszawie. W 165. rocznicę śmierci. Materiaty z ogólnopolskiej konferencji naukowej w Bibliotece Uniwersyteckiej w Warszawie, 19-20 listopada $2012 \mathrm{r}$. Red. nauk. Maria Cubrzyńska-Leonarczyk, współpr. Halina Mieczkowska, Warszawa: Wydaw. Uniwersytetu Warszawskiego 2015, s. 57-64.

133 A. ŻBIKOWSKA-MIGOŃ, Wiek XIX - stulecie bibliotek, [w:] Droga do Okólnika 18441944. W 160. rocznice powstania Biblioteki Ordynacji Krasińskich $i$ w 60. - spalenia zbiorów bibliotek warszawskich w gmachu BOK na Okólniku. Oprac. Halina Tchórzewska-Kabata, Warszawa: Biblioteka Narodowa 2005, s. 6-31.

134 Zob. też A. ŻBIKOWSKA-MIGOŃ, Z dziejów udostępniania ksią̇ki w Polsce w okresie zaborów. Studia i materiały. Pod red. Kazimiery Maleczyńskiej, Wrocław: Wydaw. Uniwersytetu Wrocławskiego 1985.

135 M. ŁODYŃSKI, Materiały do dziejów państwowej polityki bibliotecznej w Księstwie Warszawskim i Królestwie Polskim (1807-1831), Wrocław: Zakład Narod. im. Ossolińskich. Wy-

Roczniki Biblioteczne 60, 2016

(C) for this edition by CNS 
bibliotekarstwa, analizując zebrane przez siebie akty normatywne z lat 1795$1918^{136}$. Natomiast J. Włodarczyk opisał kształtowanie się zawodu bibliotekarza w podzielonej Polsce ${ }^{137}$. Należy też podkreślić wagę studiów nad rolą książki i bibliotek w integracji międzyzaborowej, podtrzymaniu i rozwoju polskiej świadomości narodowej ${ }^{138}$.

Odrębne opracowania mają dzieje bibliotek polskich Wielkiego Księstwa Poznańskiego $^{139}$, Śląska - Cieszyńskiego ${ }^{140}$ i Górnego ${ }^{141}$, Królestwa Polskiego za lata $1815-1830^{142}$ oraz pruskiej prowincji Pomorze ${ }^{143}$. Brakuje podobnych monografii m.in. dla regionów I Rzeczypospolitej, które znalazły się w graniach Rosji,

daw. Polskiej Akademii Nauk 1958; idem, Wpływ wytycznych Komisji Edukacji Narodowej na państwowa polityką biblioteczna Księstwa Warszawskiego i Królestwa Polskiego, [w:] Z dziejów książki i bibliotek w Warszawie..., s. 76-105.

136 T. ZARZĘBSKI, Prawo biblioteczne w okresie zaborów, 1795-1918, 1939-1945, Warszawa: nakładem autora 1997, s. 18-58.

137 Jerzy WŁODARCZYK, Ksztaltowanie się zawodu bibliotekarskiego na ziemiach polskich w okresie zaborów, Łódź: Wydaw. Uniwersytetu Łódzkiego 1990.

138 A. TOKARSKA, Książki, ludzie, idee. Kontakty kulturalne Górnego Śląska z Krakowem $w$ dobie niewoli narodowej, Katowice: Wydaw. Uniwersytetu Śląskiego 2003. Zob. też m.in. M. KOCÓJOWA, Nowe oferty dla badań dziejów polskiej książki w okresie zaborów, [w:] Ksiązka polska w okresie zaborów (1795-1918). Wybrane problemy metodologii i dydaktyki bibliologii, bibliotekoznawstwa i informatologii. Red. Maria Kocójowa, Kraków: Uniwersytet Jagielloński 1991, s. 13-39; Zbigniew SŁAWIŃSKI, Biblioteki a świadomość narodowa $w$ Wielkopolsce $w$ okresie zaborów, Biblioteka 1997, nr 1, s. 7-15; Bogumiła KOSMANOWA, Rola bibliotek w integracji narodowej pod zaborami, [w:] Rola książki wintegracji ziem polskich w XIX w. Pod red. Bogumiły Kosmanowej, Bydgoszcz: Wydaw. Uczelniane Akademii Bydgoskiej im. Kazimierza Wielkiego 2000, s. 9-22.

139 B. KOSMANOWA, Biblioteki polskie w Wielkim Księstwie Poznańskim, Poznań: Wydaw. Uniwersytetu Poznańskiego im. Adama Mickiewicza 1982. Zob. też eadem, Bibliotekarstwo wielkopolskie 1793-1918, Pamiętnik Biblioteki Kórnickiej 1983, z. 20, s. 129-142.

140 Maria PAWŁOWICZOWA, Książka polska i biblioteka na Ślasku Cieszyńskim w latach 1740-1920, Katowice: Wydaw. Uniwersytetu Śląskiego 1986. Zob. też m.in. Historyczne księgozbiory Cieszyna na tle ślaskim. Rola kulturowa i przedmiot badań. Pod red. Ryszarda Gładkiewicza, Cieszyn: Książnica Cieszyńska 1997.

141 A. TOKARSKA, Biblioteki polskie na Górnym Ślasku w XIX wieku, Katowice: Wydaw. Uniwersytetu Śląskiego 1997. Zob. też Książka polska na Śląsku w drugiej połowie XIX wieku. Zarys problematyki. Pod red. Marii Pawłowiczowej, Katowice: Śląsk 1992; Książka polska na Ślasku w latach 1900-1922. Zarys problematyki. Pod red. Marii Pawłowiczowej, Katowice: Śląsk 1994; Z dziejów ksiązek, bibliotek i czytelnictwa na Ślasku. Varia. Pod red. Ireny Sochy, Katowice: Wydaw. Uniwersytetu Śląskiego 1998.

142 E. SŁODKOWSKA, Biblioteki w Królestwie Polskim 1815-1830, Warszawa: Biblioteka Narodowa 1996. Zob. też m.in. Janusz KOSTECKI, Biblioteki $w$ Królestwie Polskim $w$ drugiej połowie XIX wieku. Wybrane problemy, [w:] Problemy zycia literackiego w Królestwie Polskim 2. połowy XIX wieku. Red. S. Frybes. Wrocław: Ossolineum 1983, s. 93-136; M.J. LECH, Ludzie druku i książki w Królestwie Polskim 1867-1907. Kształtowanie się struktur społecznych, Warszawa: Biblioteka Narodowa 1983; Czesław ERBER, Dzieje książki na Kielecczyźnie w latach 1795-1865, Kielce: Wyższa Szkoła Pedagogiczna im. Jana Kochanowskiego 1996.

143 Janina KOSMAN, Z dziejów bibliotek w pruskiej prowincji Pomorze w XIX i poczatkach XX wieku, Szczecin: Książnica Pomorska im. Stanisława Staszica 2013. 
lecz widoczny jest tutaj postęp w badaniach, którego wyrazem są np. prace E. Różyckiego ${ }^{144}$. Ważne są też rozprawy opisujące biblioteki jako instytucje kultury książki większych i mniejszych miejscowości, w tym Gdańska ${ }^{145}$, Krakowa ${ }^{146}$, Łodzi $^{147}$, Kalisza ${ }^{148}$ i Przemyśla ${ }^{149}$, a z mniejszych — na przykład Wisły ${ }^{150}$.

W okresie PRL interesowano się szczególnie bibliotekarstwem powszechnym ${ }^{151}$. Według Zofii Gacy-Dąbrowskiej miało to m.in. uzasadnienie polityczne, gdyż „w nowych warunkach ustrojowych, zaistniała też potrzeba szukania »korzeni« dla żywiołowo rozrastającej się sieci bibliotekarstwa publicznego, dla jego polskich tradycji na ziemiach odzyskanych" "152. Dzięki zmianom politycznym od 1989 roku rozwijają się także badania na temat bibliotekarstwa polskiego na

144 M.in. E. RÓŻYCKI, Biblioteki na Podolu w XVI-XX wieku. Wybrane zagadnienia z dziejów polskiej kultury książki, Studia Bibliologiczne (12) 2000, s. 45-67; idem, Z dziejów książki i kultury polskiej na Bracławszczyźnie w XIX-XX wieku, Studia Bibliologiczne (17) 2008, s. 125 144. Zob. też m.in. Wspólnota pamięci. Studia z dziejów kultury ziem wschodnich dawnej Rzeczypospolitej. Pod red. Jolanty Gwioździk, Jana Malickiego, Katowice: Biblioteka Śląska 2006.

145 Maria BABNIS, Książka polska w Gdańsku w okresie zaboru pruskiego (1793-1919), Wrocław: Zakład Narod. im. Ossolińskich 1989.

146 M. KOCÓJOWA, Krakowski świat książki doby autonomii galicyjskiej. Ksztaltowanie nowego modelu w latach 1867-1882, Kraków: Uniwersytet Jagielloński 1990.

147 J. KONIECZNA, Kultura ksią̇ki polskiej w Łodzi przemysłowej (1820-1918), Łódź: Wydaw. Uniwersytetu Łódzkiego 2005.

148 Danuta WAŃKA, Świat kaliskiej książki pod zaborem rosyjskim (1815-1914), Kalisz: Kaliskie Towarzystwo Przyjaciół Nauk 2002.

149 Anna SICIAK, Dzieje książki w Przemyślu w okresie autonomii Galicji (1867-1914), Przemyśl: Południowo-Wschodni Instytut Naukowy 2012.

${ }^{150}$ Książka i szkoła w Wiśle w XIX wieku. 150 lat biblioteki Jana Śniegonia. Praca zbiorowa pod red. Renaty Czyż i Danuty Szczypki, Wisła: Wydaw. Luteranin 2009.

151 M.in. Józef KORPAŁA, Z dziejów miejskich bibliotek publicznych w Galicji, [w:] Z zagadnień teorii i praktyki bibliotekarskiej. Studia poświęcone pamięci Józefa Grycza. Red. Bogdan Horodyski et al., Wrocław: Zakład Narod. im. Ossolińskich. Wydawnictwo 1961, s. 307-329; Ksawery ŚWIERKOWSKI, Rodowód Towarzystwa Biblioteki Publicznej w Warszawie, [w:] Z dziejów książki i bibliotek $w$ Warszawie..., s. 106-129; Janina KRACZKIEWICZ, Biblioteka Publiczna w latach 1907-1914, [w:] Z dziejów książki i bibliotek w Warszawie..., s. 527-546; Franciszek SZYMICZEK, Polskie biblioteki ludowe w Górnoślaskim Zagłębiu Węglowym w latach 1901-1914, Rocznik Biblioteki Narodowej (8) 1972, s. 223-242; J. WRÓBLEWSKI, Kształtowanie się i rozwój bibliotekarstwa ludowego w zaborze pruskim w latach 1843-1878, Rocznik Biblioteki Narodowej (6) 1970, s. 339-386; M.J. LECH, „Biblioteki ludowe” w Królestwie Polskim 1897-1906, Studia o Książce (3) 1973, s. 375-411; Mieczysława WEŁNA-ADRIANEK, Początki bibliotekarstwa publicznego w Lublinie, Roczniki Biblioteczne (14) 1970, z. 3/4, s. 703-724; Józef ZAJĄC, Od bibliotek społecznych do bibliotek publicznych w Krakowie, [w:] Ksiązki, czasopisma, biblioteki Krakowa XIX i XX wieku. Materiaty z Sesji Naukowej odbytej w dniach 6-7 maja 1986 r. w czterdziestolecie WSP w Krakowie. Pod red. Ryszarda Ergetowskiego, Kraków: Wydaw. Naukowe WSP 1988, s. 49-68.

152 Z. GACA-DĄBROWSKA, Sytuacja w badaniach ..., s. 71. 
kresach wschodnich ${ }^{153}$. Na gruntowne opracowanie czekają również dzieje bibliotekarstwa powszechnego mniejszości narodowych ${ }^{154}$. Istotne wyniki przyniosły studia nad działalnością czytelni i wypożyczalni ${ }^{155}$.

Zarys dziejów bibliotek szkolnych od 1773 roku do wybuchu I wojny światowej nakreślił Marcin Drzewiecki ${ }^{156}$, wykorzystując m.in. ustalenia Mieczysławy Adrianek $^{157}$. Stefan Rosołowski opisał organizacje, działalność i znaczenie bibliotek w kształceniu wojskowych w latach $1795-1831^{158}$, a Elżbieta Słodkowska scharakteryzowała ich rolę $\mathrm{w}$ polskim życiu naukowym na przełomie stuleci ${ }^{159}$. Wśród książnic uczelnianych najpełniej zostały opisane dzieje Biblioteki Uniwersyteckiej

153 Np. Książka w środowisku lwowskich rzemieślników. Cz. 1. Katalog ksią̇ek z Biblioteki Stowarzyszenia Rękodzielników „Gwiazda” we Lwowie. Cz. 2. Rejestr wypożyczeń Biblioteki Stowarzyszenia Rękodzielników „Gwiazda” we Lwowie (22 XI 1880-15 IV 1883). Oprac. Maria Konopka. Kraków: Wydaw. Naukowe Akademii Pedagogicznej 2003-2004; Oskar Stanisław CZARNIK, Z dziejów upowszechniania książki polskiej na Ukrainie, Rocznik Biblioteki Narodowej (35) 2003, s. 339-350.

${ }^{154}$ M.in. Krystyna SAMSONOWSKA, Żydowskie biblioteki i czytelnie w Krakowie $w$ XIX i XX wieku, Rocznik Biblioteki Polskiej Akademii Nauk w Krakowie (43) 1998, s. 219-232; Konrad ZIELIŃSKI, Drukarnie, księgarnie, biblioteki i czytelnie żydowskie w Lublinie do 1918 r. (Przyczynek do dziejów świeckiego życia kulturalnego Żydów lubelskich), [w:] Lublin a książka. Materiaty z konferencji naukowej zorganizowanej z okazji 50-lecia Wydziału Humanistycznego UMCS i 95-lecia Biblioteki im. H. Łopacińskiego w Lublinie. Pod red. Antoniego Krawczyka, Elżbiety Józefowicz-Wisińskiej, Lublin: Lubelskie Towarzystwo Naukowe 2004, s. 523-530; Izabela KRASIŃSKA, Biblioteki rosyjskie w Królestwie Polskim w latach 1864-1915 (Zarys problematyki), [w:] Studia z dziejów ksiażki i prasy. Przegląd badań za lata 2007-2010. Praca zbiorowa pod red. Zdzisława Kropidłowskiego, Dariusza Spychały i Katarzyny Wodniak, Bydgoszcz: Wydaw. Uniwersytetu Kazimierza Wielkiego 2010, s. 47-60.

155 M.in. J. KOSTECKI, Literatura piękna w ksiegozbiorach wypożyczalni prywatnych w Królestwie Polskim w latach 1864-1892, Rocznik Biblioteki Narodowej (12/13) 1976-1977, s. 73-98; Maria RADWAŃSKA, Wypożyczalnie płatne w Warszawie w latach 1890-1906, Studia o Książce (11) 1981, s. 153-188.

156 Marcin DRZEWIECKI, Główne kierunki działalności i organizacji bibliotek szkolnych w Polsce w latach 1773-1914, Z Badań nad Polskimi Księgozbiorami Historycznymi (5) 1981, s. 19-37.

157 M.in. M. ADRIANEK, Publiczna funkcja bibliotek szkolnych w początkach XIX wieku, Biuletyn Biblioteki Uniwersytetu Marii Curie-Skłodowskiej (32/33) 1984-1985, s. 27-40.

158 S. ROSOŁOWSKI, Książka i biblioteka $w$ procesie ksztatcenia wojskowego $w$ Polsce w okresie 1795-1831. Roczniki Biblioteczne Cz. I, (16) 1972, s. 139-186; Cz. II, (17) 1973 s. 67-108. Zob. też. m.in. Zenon RUTKOWSKI, Kartki z dziejów polskich bibliotek wojskowych dla upamiętnienia dwóchsetlecia polskich bibliotek wojskowych 1767-1967 [Cz. 2], Fragmenty dawnych polskich księgozbiorów wojskowych 1767-1831 w Centralnej Bibliotece Wojskowej w Warszawie. Katalog, Warszawa: Centralna Biblioteka Wojskowa 1967. Zob. też Kazimierz ZIELIŃSKI, Z dziejów polskich bibliotek wojskowych (1767-1918), Roczniki Biblioteczne (12) 1968, s. 141-180.

159 E. SŁODKOWSKA, Biblioteki i ich rola w rozwoju życia naukowego, [w:] Historia nauki polskiej. T. 4: 1893-1918. Cz. 1-2. Pod red. Bogdana Suchodolskiego, red. tomu Zofia Skubała-Tokarska, Wrocław: Zakład Narod. im. Ossolińskich 1987, s. 565-598. 
w Warszawie, m.in. w monografiach Heleny Kozerskiej i Oleny Błażejewicz ${ }^{160}$, oraz Biblioteki Uniwersyteckiej w Poznaniu (m. in. Artur Jazdon, Jakub Skutecki ${ }^{161}$ ). Wydanie Kroniki Biblioteki Uniwersytetu Jagiellońskiego Karola Estreichera ${ }^{162}$ stanowi niejako wstęp do opracowywanego obecnie drugiego tomu historii książnicy (za lata $1775-1918)^{163}$. O bibliotekach Wilna i Lwowa do lat 70. XX wieku w krajowej literaturze przedmiotu nie było prawie żadnych wzmianek ${ }^{164}$. Po 1989 roku sytuacja się poprawiła m.in. dzięki artykułom ogłaszanym w serii „Kraków-Lwów: książki, czasopisma, biblioteki” wydawanej od 1993 roku z inicjatywy Jerzego Jarowieckiego ${ }^{165}$. Ukazuje się też coraz więcej publikacji na temat dziewiętnastowiecznych dziejów Uniwersytetu Wileńskiego i jego biblioteki ${ }^{166}$. Ze względu na rolę w życiu naukowym i kulturalnym podzielonego kraju na pełne opracowanie zasługują biblioteki polskich towarzystw naukowych i upowszechniających naukę. Takiego studium autorstwa Jerzego Reizes-Dzieduszyckiego doczekały się biblioteki studenckie we Lwowie ${ }^{167}$,

160 H. KOZERSKA, Warszawska Biblioteka Uniwersytecka w latach 1832-1871. Biblioteka Rzadowa, Okręgu Naukowego, Główna, Warszawa: Wydaw. Uniwersytetu Warszawskiego 1967; O. BŁAŻEJEWICZ, Dzieje Biblioteki Uniwersyteckiej w Warszawie 1871-1915, Warszawa: Wydaw. Uniwersytetu Warszawskiego 1990. Zob. też m.in. Wiesława LASZCZKOWSKA, Z dziejów księgozbioru Warszawskiego Gabinetu Zoologicznego (1819-1915), Wrocław: Zakład Narod. im. Ossolińskich, Wydaw. Polskiej Akademii Nauk 1974; Zofia STRZYŻEWSKA, Konfiskaty warszawskich zbiorów publicznych po Powstaniu Listopadowym. Biblioteka Uniwersytetu Warszawskiego $i$ Warszawskie Towarzystwo Przyjaciót Nauk. Materiaty i dokumenty z archiwów rosyjskich, Warszawa: DiG 2000; Kultura artystyczna Uniwersytetu Warszawskiego. Ars et educatio. Red. nauk. Jerzy Miziołek, Warszawa: Uniwersytet Warszawski 2003, zwłaszcza s. 259-273, 387-430.

161 A. JAZDON, Z kart historii Biblioteki Uniwersyteckiej w Poznaniu, Jakub SKUTECKI, Takie byly początki, Poznań: Biblioteka Uniwersytecka, 2003 (CD-ROM). Zob. też m.in. Stanisław KUBIAK, Biblioteka Uniwersytetu im. Adama Mickiewicza w Poznaniu 1919-1966, Poznań: Wydaw. Uniwersytetu im. Adama Mickiewicza 1967; Dokumentacja działalności Biblioteki Głównej Uniwersytetu im. Adama Mickiewicza w Poznaniu 1919-1979. Z. 1. Historia Biblioteki. Red. nauk. Stanisław Kubiak, Poznań: [s.n.] 1979.

162 Karol ESTREICHER, Kronika Biblioteki Uniwersytetu Jagiellońskiego od 1811 roku. Oprac. Jan Brzeski, Kraków: Biblioteka Jagiellońska 2012.

163 Biblioteka Jagiellońska - opracowanie dziejów od 1775 do 1918 r., http://www.bj.uj.edu. pl/biblioteka-jagiellonska-opracowanie-dziejow [dostęp: 29 IV 2016].

164 Do wyjątków należał artykuł Małgorzaty STOLZMAN, Księgozbiory wileńskie w okresie międzypowstaniowym (1831-1863), Biuletyn Biblioteki Jagiellońskiej (30) 1980, nr 1/2, s. 87-101. 165 Tom z 1993 r. pod tytułem Książki, czasopisma, biblioteki Krakowa i Lwowa XIX i XX wieku. Pod red. J. Jarowieckiego, Kraków: Wydaw. Naukowe Wyższej Szkoły Pedagogicznej.

166 Np. K. BEDNARSKA-RUSZAJOWA, „Dziennik pożyczania ksiażek z Biblioteki Uniwersytetu Wileńskiego" 1805-1816. Poeci w lekturach i lektury poetów - analiza kilku faktów bibliologicznych zapisanych w źródle, Z Badań nad Polskimi Księgozbiorami Historycznymi (Tom specjalny) 1993, s. 247-252.

167 Jerzy REIZES-DZIEDUSZYCKI, Książka i biblioteka $w$ działalności polskich towarzystw naukowych młodzieży akademickiej we Lwowie w okresie autonomii galicyjskiej, Katowice: Wydaw. Uniwersytetu Śląskiego 2005. Zob. też m.in. Jan REITER, Biblioteki polskich towarzystw akademickich we Wrocławiu w XIX wieku, Zeszyty Naukowe Uniwersytetu Wrocławskiego Seria 
zaś dokonania wileńskich towarzystw i instytucji naukowych opisała Henryka Ilgiewicz $^{168}$.

Zbyt mało wiemy o bibliotekach organów i instytucji państwowych ${ }^{169}$ oraz o bibliotekach kościelnych i zakonnych. Dzieje tych ostatnich w Królestwie Polskim (1815-1830) opracowała E. Słodkowska ${ }^{170}$. Ukazało się też wiele obszerniejszych rozpraw poświęconych bibliotekom kapituł katedralnych i kolegiackich ${ }^{171}$ oraz zakonnym (m.in. monografie Jolanty Małgorzaty Marszalskiej i Waldemara Graczyka) ${ }^{172}$. W przypadku bibliotek wielkoziemiańskich przedmiotem studiów były m.in. motywacje kolekcjonerów w kontekście „mecenatu bibliotecznego”, a także bibliofilstwa, gromadzenia zbiorów na własny użytek, z powodów prestiżowych czy mody ${ }^{173}$. Z oczywistych względów największym zainteresowaniem

A nr 4 Bibliotekoznawstwo 1956, s. 77-119; Urszula PASZKIEWICZ, Narastanie księgozbioru Biblioteki Towarzystwa Przyjaciół Nauk w Warszawie (1802-1832), Z Badań nad Polskimi Księgozbiorami Historycznymi (3) 1977, s. 57-100; eadem, Źródła do zawartości bibliotek polskich towarzystw naukowych $i$ upowszechniajacych nauke na ziemiach polskich $w$ okresie zaborów, Z Badań nad Polskimi Księgozbiorami Historycznymi (3) 1977, s. 195-207; Grażyna WRONA, Biblioteki i księgozbiory krakowskich towarzystw naukowych do roku 1917, Rocznik Naukowo-Dydaktyczny WSP w Krakowie. Prace Bibliotekoznawcze 7 (155) 1993, s. 25-40.

168 Henryka ILGIEWICZ, Wileńskie towarzystwa i instytucje naukowe w XIX wieku, Toruń: Wydaw. Adam Marszałek 2005.

169 M.in. Wanda STUMMER, Biblioteka Sadu Apelacyjnego w Warszawie 1810-1865, Wrocław: Państwowe Wydawnictwo Naukowe 1958; M.J. LECH, Biblioteka Komisji Rzadowej Przychodów i Skarbu, 1806-1872, Rocznik Biblioteki Narodowej (2) 1966, s. 362-378; Diana PIETRUCH-REIZES, Biblioteka Wydziału Krajowego we Lwowie 1861-1914, [w:] Kultura ksiązki ziem wschodniego i południowego pogranicza Polski (XVI-XX wiek) (paralele i różnice). Red. nauk. Jolanta Gwioździk i Edward Różycki, Katowice: Wydaw. Uniwersytetu Śląskiego 2004, s. 373-383.

170 E. SŁODKOWSKA, Biblioteki w Królestwie Polskim w latach 1815-1830. Cz. 2. Biblioteki kościelne, [w:] Instytucje — publiczność - sytuacje lektury i studia z historii czytelnictwa. Pod red. Janusza Kosteckiego. T. 5, Warszawa: Biblioteka Narodowa 1994, s. 11-98.

171 M.in. J. RYŁ, Losy Biblioteki Katedralnej w Gnieźnie pod zaborem pruskim, Roczniki Biblioteczne (29) 1985, s. 349-364; Halina KEFERSTEIN, Biblioteka kolegiacka w Dobrym Mieście. Zarys historyczny i próba charakterystyki zbiorów od początków do 1814 roku, Studia Warmińskie (30) 1996, s. 301-336.

172 J.M. MARSZALSKA, Biblioteka opactwa Cystersów w Szczyrzycu do końca XIX stulecia. Dziedzictwo wieków, Tarnów: Wydaw. Diecezji Tarnowskiej Biblos 2007; W. GRACZYK, Księgozbiór klasztoru-eremu karmelitów bosych w Czernej od XVII do końca XIX wieku. Studium $z$ dziejów kultury intelektualnej $i$ duchowej, Kraków: Wydaw. Instytutu Teologicznego Księży Misjonarzy 2011. Zob. też m.in. Waldemar KARPUK, Biblioteka marianów w Puszczy Korabiewskiej (Mariańskiej) na podstawie inwentarza z 1845 roku, Archiwa Biblioteki i Muzea Kościelne (69) 1998, s. 171-398; Paweł SKALSKI, Biblioteka Klasztoru Paulinów w Krakowie na Skatce do połowy XIX wieku, Studia Claromontana (23) 2005, s. 273-564; Agnieszka ZDROJEWSKA, Biblioteka oo. Franciszkanów Reformatów w Węrowie na podstawie inwentarza z 1854 roku, Kościół w Polsce (4) 2005, s. 89-143.

173 Zob. m.in. H. CHAMERSKA, Mecenat biblioteczny w Polsce okresu zaborów, [w:] Inteligencja polska XIX i XX wieku. Studia. T. 6. Pod red. Ryszardy Czepulis-Rastenis, Warszawa: 
historyków cieszyły się biblioteki służące zachowaniu piśmienniczego dziedzictwa narodowego i badań naukowych ${ }^{174}$. Dziewiętnastowieczne dzieje Biblioteki Zakładu Ossolińskich odtworzył m.in. Józef Adam Kosiński175, Kórnickiej Ryszard Marciniak i Andrzej Mężyński oraz Bogumiła i Marceli Kosmanowie ${ }^{176}$, Raczyńskich i jej założyciela — B. Kosmanowa i Witold Molik ${ }^{177}$, Ordynacji Zamojskiej - Bogdan Horodyski ${ }^{178}$, a kolekcji Emeryka Hutten-Czapskiego Maria Kocójowa ${ }^{179}$. Natomiast Jadwiga Rudnicka opracowała historię Biblioteki Wilanowskiej, Maria Nitkiewicz — Łańcuckiej ${ }^{180}$, Józef Wojakowski zaś- księ-

Państwowe Wydawnictwo Naukowe 1991, s. 27-71; A. MĘŻYŃSKI, Wielkoziemiańskie biblioteki publiczne w Polsce w latach 1772-1918, Roczniki Biblioteczne (46) 2002, s. 211-242; Kazimierz OSSOWSKI, O bibliofobii i sposobach jej leczenia na przetomie XVIII $i$ XIX w., [w:] Ludzie i książi. Studia historyczne. Pod red. Janusza Kosteckiego, Warszawa: Biblioteka Narodowa 2006, s. $59-89$.

174 M.in. Krystyna KORZON, Polskie biblioteki fundacyjne w okresie zaborów, Pamiętnik Biblioteki Kórnickiej (17) 1981, s. 255-261; Józef Adam KOSIŃSKI, Biblioteki fundacyjne i ordynackie w świetle przepisów prawnych, Roczniki Biblioteczne (35) 1981, z. 1/2, s. 29-40; Ryszard MARCINIAK, A. MĘŻYŃSKI, Polskie biblioteki wielkoziemianskie (rodowe, ordynackie, fundacyjne) w okresie zaborów. Stan badań i postulaty badawcze. Studia o Książce Cz. 1, (15) 1985, s. 191-209; Cz. 2, (16) 1986, s. 235-263.

175 J.A. KOSIŃSKI, Biblioteka fundacyjna Józefa Maksymiliana Ossolińskiego, Wrocław: Zakład Narod. im. Ossolińskich 1971. Zob. też m.in. idem, Maria TURALSKA, Ofiarodawcy Biblioteki Ossolineum 1817-1848, Wrocław: Zakład Narod. im. Ossolińskich 1968; Irena LEWANDOWSKA-JARACZEWSKA, Zakład Narodowy im. Ossolińskich za dyrektury Adama Kłodzińskiego, 1839-1849, Wrocław: Zakład Narod. im. Ossolińskich 1980.

176 R. MARCINIAK, Biblioteka Kórnicka Tytusa Działyńskiego w r. 1826, Pamiętnik Biblioteki Kórnickiej 1976 z. 12, s. 7-18; A. MĘŻYŃSKI, Biblioteka Kórnicka Jana Działyńskiego, Pamiętnik Biblioteki Kórnickiej 1976 z. 12, s. 117-175; R. MARCINIAK, A. MĘŻYŃSKI, Biblioteka Kórnicka - zarys historii, Studia o Książce (7) 1977, s. 3-31; B. i M. KOSMANOWIE, Tytus Działyński i jego dzieło. 150 lat Biblioteki Kórnickiej, Wrocław: Zakład Narod. im. Ossolińskich 1978; M. KOSMAN, Z dziejów biblioteki Kórnickiej, Zakład Narod. im. Ossolińskich 1984. Zob. też A. MĘŻYŃSKI, Jan Działyński 1829-1880, Zakład Narod. im. Ossolińskich 1987.

177 B. KOSMANOWA, Edward Raczyński - człowiek i dzieło, Bydgoszcz: Wydaw. Uczelniane Wyższej Szkoły Pedagogicznej w Bydgoszczy 1997; Witold MOLIK, Edward Raczyński 1786-1845, Poznań: Wojewódzka Biblioteka Publiczna w Poznaniu 1999. Zob. też m.in. Alfred KACZKOWSKI, Biblioteka Raczyńskich, Warszawa; Poznań: Państwowe Wydawnictwo Naukowe 1978; Kazimierz EWICZ, Dzieje Biblioteki w latach 1829-1945, [w:] Miejska Biblioteka Publiczna im. Edwarda Raczyńskiego w Poznaniu 1829-1979. Sto pięćdziesiąt lat w stużbie narodu, Warszawa; Poznań: Państwowe Wydawnictwo Naukowe 1979, s. 15-45.

178 B. HORODYSKI, Zarys dziejów Biblioteki Ordynacji Zamojskiej, [w:] Studia nad książka poświęcone pamięci Kazimierza Piekarskiego, Wrocław: Wydaw. Zakładu Narod. im. Ossolińskich 1951, s. 295-341.

179 M. KOCÓJOWA, „Pamiątkom ojczystym ocalonym z burzy dziejowej”. Muzeum Emeryka Hutten-Czapskiego (Stańków-Kraków), Kraków: Wydaw. Literackie 1978.

180 J. RUDNICKA, Biblioteka Wilanowska. Dwieście lat jej dziejów 1741-1932, Warszawa: Biblioteka Narodowa 1967; M. NITKIEWICZ, Biblioteka i życie kulturalne łańcuckiej rezydencji, 
gozbiorów Kajetana Sapiehy i Wacława Seweryna Rzewuskiego ${ }^{181}$. Badania objęły także biblioteki: Baworowskich we Lwowie ${ }^{182}$, Czartoryskich w Krakowie i Sieniawie ${ }^{183}$, Lubomirskich w Przeworsku ${ }^{184}$, Tarnowskich w Dzikowie ${ }^{185}$ oraz Branickich i Tarnowskich w Suchej Beskidzkiej ${ }^{186}$. Jednak poziom wiedzy na temat bibliotek wielkoziemiańskich jest niezadowalający, przy czym prace utrudnia fragmentaryczność i rozproszenie źródeł ${ }^{187}$.

Studia nad dziewiętnastowiecznymi bibliotekami (księgozbiorami) domowymi stanowią zatem duże wyzwanie. Kolekcje te znikały bowiem wskutek zawieruch dziejowych XIX i XX wieku ${ }^{188}$, działów spadkowych czy sprzeda-

Łańcut: Muzeum-Zamek w Łańcucie 1986. Zob. też Aldona CHOLEWIANKA-KRUSZYŃSKA, Daniel RENISZEWSKI, Biblioteka Julińska. Dzieje towiecko-leśnego księgozbioru Potockich z Łańcuta, Łańcut: Muzeum — Zamek 2015.

181 J. WOJAKOWSKI, Ksiegozbiory Eustachego Kajetana Sapiehy (1797-1860) i Wactawa Seweryna Rzewuskiego (1785-1831), Warszawa: DiG 1996.

182 Bibliotheca Bavoroviana Leopoliensis. Prints from the first half of the sixteenth century. A catalogue. Red. Jolanta Gwoździk, Tadeusz Maciąg, współpraca Iwona Pietrzkiewicz, Renata Frączek, Katowice: Wydaw. Uniwersytetu Śląskiego 2015. Zob. też m.in. Agnieszka CHAMERA-NOWAK, Zarys problematyki dotyczacej Biblioteki Fundacji Wiktora hr. Baworowskiego, Czasopismo Zakładu Narod. im. Ossolińskich (18/19) 2008, s. 55-64.

183 M.in. Janusz NOWAK, Ordynacja sieniawska książat Czartoryskich. Plany-zamierzenia - realizacja, Roczniki Biblioteki PAU i PAN w Krakowie 45 (2000), s. 121-159.

184 M.in. Mieczysław GAŁYGA, Sprawa wcielenia księgozbioru przeworskiego Lubomirskich do Ossolineum w latach 1823-1876, Rocznik Zakładu Narod. im. Ossolińskich (7) 1972, s. $69-86$.

185 M.in. Aleksandra JANAS, Kolekcja dzikowska hr. Tarnowskich, Tarnobrzeg: Muzeum Historyczne Miasta Tarnobrzega 2006; Katarzyna PADUCH, Jan Feliks Tarnowski i jego dzikowska biblioteka na przełomie XVIII i XIX wieku, Saeculum Christianum (20) 2013, s. $131-$ 148 .

186 Helena MAŁYSIAK, Biblioteka Branickich i Tarnowskich w Suchej, Bielsko-Biała: Beskidzka Oficyna Wydawnicza BTSK 1986.

187 Np. w przypadku zbiorów Potockich z Tulczyna zob. m.in. Bogumiła SCHNAJDROWA, Fragment zbiorów tulczyńskich w rękopisach Biblioteki Polskiej Akademii Nauk w Krakowie, Rocznik Biblioteki Polskiej Akademii Nauk w Krakowie (15) 1969, s. 89-102; Alina DZIĘCIOŁ, Książki Potockich z Tulczyna w zbiorach starych druków w Zamku Królewskim, Kronika Zamkowa (4/12) 1987, s. 14-17; Maria STRUTYŃSKA, Stare druki proweniencji Potockich z Tulczyna w zbiorach Biblioteki Uniwersytetu Mikołaja Kopernika w Toruniu, Z Badań nad Polskimi Księgozbiorami Historycznymi (14) 1992, s. 161-217; Grażyna ROLAK, W kręgu Potockich z Tulczyna. Fragment kolekcji Biblioteki Tulczyńskiej w zbiorach Dziatu Starych Druków Zakładu Narodowego im. Ossolińskich, Czasopismo Zakładu Narod. im. Ossolińskich (15) 2004, s. 157-181; Lidia KOWKIEL, Prywatny księgozbiór Potockich z Tulczyna w kolekcji Muzeum Historyczno-Archeologicznego w Grodnie, [w:] Ród Potockich w odmęcie historii (XVII-XX w.). Pod red. Zdzisława Janeczka, Katowice: Wydaw. Akademii Ekonomicznej im. Karola Adamieckiego 2007, s. 503-521.

188 Zob. m.in. Czesław ERBER, Z konfiskat księgozbiorów uchodźstwa politycznego po powstaniu listopadowym. Biblioteka Jana Olrycha Szanieckiego, Kielce: Koło Naukowe Bibliologów Wyższej Szkoły Pedagogicznej im. Jana Kochanowskiego, Wojewódzka Biblioteka Publiczna 1989; Bogdan JASTRZĘBSKI, Biblioteka hrabiów Ostrowskich z Ujazdu, Z Badań nad Polskimi Księgozbiorami Historycznymi (7) 1985, s. 159-173. 
ży ${ }^{189}$. Są zatem często „bibliotekami, których nie ma”, jak to określiła Agnieszka Chamera-Nowak w tytule monografii księgozbioru Andrzeja Edwarda Koźmiana ${ }^{190}$. Mimo to pojawiają się kolejne opracowania zawierające ważne ustalenia na temat roli i znaczenia prywatnego gromadzenia książek oraz ich użytkowania, m.in. Józefa Szockiego (w Galicji Wschodniej ${ }^{191}$ ), Lilii Kowkiel (na Grodzieńszczyźnie $^{192}$ ) i Anny Dymmel (w Lublinie ${ }^{193}$ ). Luki w tym zakresie stopniowo uzupełniają także badania nad kulturą książki poszczególnych warstw i grup społecznych oraz środowisk (m.in. prace Bożeny Koredczuk ${ }^{194}$ ) oraz rozprawy i edycje źródłowe na temat kolekcji prywatnych, np. Jacka Idziego Przybylskiego ${ }^{195}$, Stanisława Staszi$\mathrm{ca}^{196}$, Konstantego Świdzińskiego ${ }^{197}$, Józefa Ignacego Kraszewskiego ${ }^{198}$, Józefa

189 Zob. m.in. Jan WEGNER, Biblioteka Nieborowska, Rocznik Muzeum Narodowego w Warszawie (5) 1960, s. 211-266.

190 A. CHAMERA-NOWAK, Biblioteka, której nie ma... Andrzej Edward Koźmian i jego książki, Warszawa: Wydaw. SBP 2015.

191 Józef SZOCKI, Księgozbiory domowe w Galicji wschodniej (1772-1918), Kraków: Wydaw. Naukowe Akademii Pedagogicznej 2001.

192 L. KOWKIEL, Prywatne księgozbiory na Grodzieńszczyźnie w pierwszej połowie XIX wieku, Kraków: Wydaw. Naukowe Akademii Pedagogicznej 2005.

193 A. DYMMEL, Ksiegozbiory domowe w Lublinie w pierwszej połowie XIX wieku, Lublin: Wydaw. Uniwersytetu Marii Curie-Skłodowskiej 2013.

194 B. KOREDCZUK, Udziat inteligencji prawniczej Królestwa Polskiego w kształtowaniu kultury książki (1815-1915), Wrocław: Wydaw. Uniwersytetu Wrocławskiego 2011. Zob. też m.in. Andrzej SKRZYPCZAK, Księgozbiory lekarzy warszawskich XIX wieku jako podstawa do oceny kultury naukowej środowiska, Z Badań nad Polskimi Księgozbiorami Historycznymi (7) 1985, s. 115-151; Hanna TADEUSIEWICZ, Udział lekarzy w rozwoju książki i bibliotek $w$ Polsce, Zeszyty Naukowe Kaliskiego Towarzystwa Lekarskiego 1999 nr 5, s. 90-106; H. CHAMERSKA, Rola kobiet $w$ mecenasie bibliotecznym $w$ okresie zaborów, [w:] Kobieta i edukacja na ziemiach polskich w XIX $i$ XX w. Zbiór studiów. T. 2. Cz. 2. Pod red. Anny Żarnowskiej i Andrzeja Szwarca, Warszawa: Instytut Historyczny Uniwersytetu Warszawskiego 1992, s. 293-303; Jan LEOŃCZUK, Chtopskie księgozbiory domowe. Kulturowe uwarunkowania tworzacych się zbiorów domowych i pamiatek na terenie gminy Zabludów od końca XIX wieku, Z Badań nad Polskimi Księgozbiorami Historycznymi (21) 2003, s. 137-160.

195 Ksieggozbiór prywatny Jacka Idziego Przybylskiego w zbiorach Biblioteki Jagiellońskiej w Krakowie. Oprac. Małgorzata Mirek, Kraków: Księgarnia Akademicka 2010.

196 U. PASZKIEWICZ, Księgozbiór Stanisława Staszica w Bibliotece Uniwersyteckiej $w$ Warszawie. Studium proweniencyjne, Z Badań nad Polskimi Księgozbiorami Historycznymi (9) 1986, s. 79-123.

197 Konrad AJEWSKI, Kolekcjonerstwo Konstantego Świdzińskiego, Rocznik Biblioteki Narodowej (36) 2006, s. 21-78.

198 Kilka artykułów Jerzego JAROWIECKIEGO, w tym Księgozbiór Józefa Ignacego Kraszewskiego - warsztatem pracy pisarza i historyka, Zeszyty Naukowe Uniwersytetu Szczecińskiego. Prace Polonistyczne 1991, nr 3, s. 69-92; Anna GOJNICZEK, Biblioteka Józefa Ignacego Kraszewskiego, Pamiętnik Cieszyński (10) 1995, s. 47-65. 
Szujskiego ${ }^{199}$, a także Bolesława Prusa ${ }^{200}$, Hieronima Łopacińskiego ${ }^{201}$ czy Stanisława Leszczyńskiego ${ }^{202}$.

Ważnym polem badawczym bibliologii historycznej powinny być dzieje bibliotek polskich na obczyźnie, o co upominał się Andrzej Kłossowski ${ }^{203}$. W tym przypadku najlepiej rozpoznana została dziewiętnastowieczna przeszłość Biblioteki Polskiej w Paryżu (m.in. dzięki pracom Janusza Pezdy ${ }^{204}$ ). Zajmowano się też bibliotekami: Wersalską i Szkoły Polskiej w Batignolles, Polską w Rumunii 205 oraz kolekcją Artura Wołyńskiego i Biblioteką Polską w Rzymie (m.in. Jan Piskurewicz $\left.{ }^{206}\right)$. Dodać należy zarys dziejów Biblioteki Towarzystwa Naukowego Akademików Polaków w Berlinie Ryszarda Ergetowskiego ${ }^{207}$ i rozprawę Jacka Kuszłejki na temat książki polskiej w Rosji (1993) ${ }^{208}$. Historię Biblioteki Muze-

199 J. SZOCKI, Księgozbiór domowy Józefa Szujskiego (w świetle sporzadzonych jego ręka katalogów). Cz. 1-2, Biuletyn Biblioteki Jagiellońskiej (39) 1989, s. 101-119 i (40) 1990, s. 33-124. 200 Halina ILMURZYŃSKA, Agnieszka STEPNOWSKA, Księgozbiór Bolesława Prusa. Red. nauk. Zygmunt Szweykowski, Warszawa: SBP 1965.

201 Adrian ULJASZ, Hieronim Łopaciński 1860-1906. Człowiek, dzieło, pamięć, Lublin: Wojewódzka Biblioteka Publiczna im. Hieronima Łopacińskiego 2006.

202 Spuścizna Stanisława Leszczyńskiego w zbiorach Biblioteki Publicznej m. st. Warszawy. Oprac. zespół pod kier. Romana Nowoszewskiego, Warszawa: Biblioteka Publiczna m. st. Warszawy. Biblioteka Główna Województwa Mazowieckiego 2007.

203 Andrzej KŁOSSOWSKI, Historia ksiązki polskiej za granica, Problemy badawcze, Warszawa: Biblioteka Narodowa 1980. Zob. m.in. 11 informatorów wydanych w latach 1982-2000 przez Bibliotekę Narodową w serii „Zbiory i Prace Polonijne Bibliotek Polskich”.

204 Janusz PEZDA, Historia Biblioteki Polskiej w Paryżu w latach 1838-1893, Kraków: Towarzystwo Wydawnicze Historia Iagellonica 2013. Zob. też m.in. Katarzyna SEROKA, Karol Sienkiewicz (1793-1860) — pierwszy dyrektor Biblioteki Polskiej w Paryżu, [w:] Wzory i wzorce osobowe w biografistyce pedagogicznej. Red. Ryszard Skrzyniarz, Magdalena Gajderowicz, Tomasz Wach, Lublin: Wydaw. Episteme 2013, s. 155-169.

205 M.in. Władysława JABŁOŃSKA, Biblioteka Polska w Rumunii i jej wpływ na powstanie Towarzystwa Przyjaciót Nauk na Śląsku, Roczniki Biblioteczne (4) 1960, z. 3/4, s. 477-520; D. BOLEWSKA, Biblioteka Batignolska jako depozyt w Kórniku (1874-1925), Pamiętnik Biblioteki Kórnickiej 1974 z. 11, s. 5-22; Iwona H. PUGACEWICZ, Organizacja i plany wobec Biblioteki Wersalskiej w świetle wybranych relacji źródłowych, Z Badań nad Książką i Księgozbiorami Historycznymi (6) 2012, s. 275-288.

206 Jan PISKUREWICZ, Z ziemi włoskiej dla Polski. Artur Wotyński i jego działalność w Italii $w$ drugiej połowie XIX wieku, Warszawa: Wydaw. Uniwersytetu Kardynała Stefana Wyszyńskiego 2012. Zob. też Tomasz JAKUBOWSKI, Kolekcja grafiki Artura Wolyńskiego w Bibliotece Casanatense w Rzymie, [w:] Stan badań nad wielokulturowym dziedzictwem dawnej Rzeczypospolitej. T. 2. Red. nauk. Wojciech Walczak i Karol Łopatecki, Białystok: Instytut Badań nad Dziedzictwem Kulturowym Europy 2010, s. 103-112.

207 Ryszard ERGETOWSKI, Biblioteka Towarzystwa Naukowego Akademików Polaków w Berlinie 1868-1919, Roczniki Biblioteczne (31) 1987, z. 2, s. 2-29.

208 Jacek KUSZŁEJKO, Ksią̇ka polska w Rosji na przełomie XIX i XX wieku, Warszawa: Biblioteka Narodowa 1993. Zob. też m.in. A. KŁOSSOWSKI, Ksiażka polska w Petersburgu (1773-1920), Acta Universitatis Lodziensis Folia Librorum (6) 1995, s. 19-32. 
um Polskiego w Rapperswilu ujęto m.in. w bibliotekarskich biografiach Stefana Żeromskiego i Stanisława Zielińskiego ${ }^{209}$.

Studia biograficzne mają istotne znaczenie także dla krajowego obrazu bibliotekarstwa w XIX wieku, zwłaszcza poświęcone Joachimowi Lelewelowi (przede wszystkim Ireny Treichel, Witolda Nowodworskiego, Heleny Więckowskiej ${ }^{210}$ ), Tadeuszowi Czackiemu ${ }^{211}$, Samuelowi Bogumiłowi Lindemu ${ }^{212}$, Jerzemu Samuelowi Bandtkiemu ${ }^{213}$, Karolowi Estreicherowi ${ }^{214}$, Wojciechowi Kętrzyńskiemu ${ }^{215}$, Franciszkowi Szczepańskiemu ${ }^{216}$ czy Stanisławowi Kośmińskiemu ${ }^{217}$.

Okres dwudziestolecia międzywojennego opisała Zofia Gaca-Dąbrowska w rozprawie Bibliotekarstwo II Rzeczypospolitej (Wrocław 1983). Tę podstawową pracę uzupełniła książka Jerzego Włodarczyka o zawodzie bibliotekarskim ${ }^{218}$, analiza aktów prawnych zestawionych przez T. Zarzębskiego ${ }^{219}$ i studia Jadwi-

209 Bartłomiej SZYNDLER, Bibliotekarska stużba Stefana Żeromskiego, Wrocław: Ossolineum 1977; Beata BARTCZAK, Stanisław Zieliński-bibliotekarz, bibliograf, publicysta, Toruń: Adam Marszałek 2000. Zob. też m.in. Stanisław CHANKOWSKI, Muzeum Rapperswilskie jako warsztat pracy naukowej, Przegląd Historyczny (79) 1988, nr 1, s. 43-62; Ewa GAŁYGA, Polemika wokół Muzeum Narodowego Polskiego w Rapperswilu i jego biblioteki w latach 1910-1911. Geneza, przebieg, następstwa, Roczniki Biblioteczne (30) 1986, z. 1/2, s 71-98.

210 Irena TREICHEL, Pierwszy polski podręcznik bibliotekarski, Roczniki Biblioteczne (1) 1957, z 1/2, s. 167-230; Witold NOWODWORSKI, ,Bibliograficznych ksiag dwoje” Joachima Lelewela. Studium historyczno-bibliograficzne na tle epoki, Wrocław: Zakład Narod. im. Ossolińskich 1959; H. WIĘCKOWSKA, Joachim Lelewel uczony - polityk - człowiek, Warszawa: Czytelnik 1980. Zob. też m.in. Joachim Lelewel - księgoznawca, bibliotekarz, bibliograf. Red. nauk. Maria Magdalena Biernacka, Warszawa: Wydaw. Uniwersytetu Warszawskiego 1993; Bogumił KARKOWSKI, Dzieje bibliotek Joachima Lelewela. Studium bibliologiczne, Łódź: Wydaw. Uniwersytetu Łódzkiego 1995.

211 Ewa DANOWSKA, Tadeusz Czacki 1765-1813. Na pograniczu epok, Kraków: Polska Akademia Umiejętności 2006.

212 O. BŁAŻEJEWICZ, Samuel Bogumit Linde — bibliotekarz i bibliofil, Wrocław 1975.

213 M.in. Aleksandra GAJOWSKA, Działalność bibliotekarska Jerzego Samuela Bandtkiego, Studia Bibliologiczne (18) 2010, s. 109-132.

214 Jan BAUMGART, Karol Estreicher jako bibliotekarz, [w:] Księga pamiątkowa ku czci Karola Estreichera, 1827-1908. Studia i rozprawy. Red. Jan Baumgart et al., Kraków: Wydaw. Literackie 1964, s. 133-197.

215 K. KORZON, Wojciech Kętrzyński 1838-1918. Zarys biograficzny, Wrocław: Zakład Narod. im. Ossolińskich 1993.

216 J. WRÓBLEWSKI, Działalność bibliotekarska Franciszka Szczepańskiego, Olsztyn: Stacja Naukowa Polskiego Towarzystwa Historycznego 1968.

217 Beata MAUER-GÓRSKA, Stanisław Kośmiński (1837-1883). Lekarz, bibliotekarz i bibliograf, Warszawa: Główna Biblioteka Lekarska 2002.

218 J. WŁODARCZYK, Bibliotekarze w Polsce okresu międzywojennego, Łódź: Wydaw. Uniwersytetu Łódzkiego 1988.

219 T. ZARZĘBSKI, Polskie prawo biblioteczne 1773-1990. Wyd. 2 rozsz., Warszawa: Biblioteka Narodowa 1991, zob. s. 25-31, 79-104.

Roczniki Biblioteczne 60, 2016

(C) for this edition by CNS 
gi Kołodziejskiej o bibliotekach w strukturze społecznej II RP220. Kilku istotnych opracowań doczekały się dzieje bibliotek na Śląsku, pióra m.in. Henryka Rechowicza, Małgorzaty Gwadery i Bogumiły Warząchowskiej221. Działalność placówek oświatowych na Lubelszczyźnie przedstawił Jerzy Plis ${ }^{222}$, a na Mazowszu Monika Olczak-Kardas ${ }^{223}$. Biblioteki Wileńszczyzny opisuje obok innych instytucji książki wydawnictwo encyklopedyczne opracowane przez Mieczysława Jackiewicza ${ }^{224}$. Ukazały się też obszerne studia na temat bibliotek Kalisza $\left(\right.$ Krzysztof Walczak $^{225}$ ), Białegostoku ${ }^{226}$, Krzemieńca ${ }^{227}$ oraz zarysy historii bibliotek Gdańska ${ }^{228}$ i artykuły opisujące funkcjonowanie placówek różnego typu m.in. w Krakowie ${ }^{229}$ i Łodzi ${ }^{230}$. Przy badaniach nad dziejami bibliotekarstwa w poszczególnych regionach, subregionach i miejscowościach pomocne mogą być

220 J. KOŁODZIEJSKA, Biblioteki publiczne w strukturze społecznej, Warszawa: Wydaw. SBP 2010, s. 88-128 i in. Zob. też m.in. eadem, Publiczne biblioteki samorzadowe w okresie międzywojennym, Warszawa: SBP 1967.

221 Ksiązka polska na Śląsku w latach 1922-1945. Zarys problematyki. Pod red. Marii Pawłowiczowej, Katowice: Śląsk 1994; Henryk RECHOWICZ, Poprzedniczki Biblioteki Ślaskiej i ich rola w życiu umysłowym województwa ślaskiego, Katowice: Śląski Instytut Naukowy 1990; M. GWADERA, Polskie księgozbiory pedagogiczne w województwie śląskim w latach 1922-1939, Katowice: Wydaw. Uniwersytetu Śląskiego 2005. Zob. też Małgorzata OLSZÓWKA, Urszula WOŁCZYK, Biblioteki pedagogiczne i działalność naukowa nauczycieli w województwie ślaskim (1922-1939), Katowice: Wydaw. Uniwersytetu Śląskiego 2000; B. WARZĄCHOWSKA, Książka, prasa i biblioteka $w$ działalności Kościoła katolickiego w województwie śląskim (1922-1939), Katowice: Księgarnia św. Jacka 2012.

222 Jerzy PLIS, Biblioteki oświatowe w Lubelskiem (1918-1939), Lublin: Agencja Wydawniczo-Handlowa AD 1993.

223 Monika OLCZAK-KARDAS, Ksiegozbiory bibliotek wiejskich $w$ województwie warszawskim w latach 1918-1939, Kielce: Wydaw. Antykwaryczne 2007.

${ }^{224}$ Książka i prasa na ziemi wileńskiej. Drukarnie, wydawnictwa, księgarnie, biblioteki, czasopisma XVI w.-1945 r. Oprac. M. Jackiewicz, Bydgoszcz: Towarzystwo Miłośników Wilna i Ziemi Wileńskiej 2008.

${ }^{225}$ Krzysztof WALCZAK, Biblioteki Kalisza i ich miejsce w życiu kulturalnym miasta 1793 1945, Kalisz: Kaliskie Towarzystwo Przyjaciół Nauk 1996.

226 Zofia SOKÓŁ, Dzieje bibliotek w Białymstoku (od XVIII wieku do 1939 roku), Białystok: Wojewódzka Biblioteka Publiczna im. Łukasza Górnickiego 1999.

227 Kazimierz WARDA, Szkice z dziejów szkół krzemienieckich. Biblioteki liceum, ich zasoby i losy, Kielce: Wyższa Szkoła Pedagogiczna im. Jana Kochanowskiego 2000.

228 Marek ANDRZEJEWSKI, Biblioteki w międzywojennym Gdańsku, Gdańsk: Marpress 1995; Iwona NIECHCIAŁ, Biblioteki polskie w Wolnym Mieście Gdańsku (1920-1939), Pelplin: Bernardinum 2000.

229 Piotr LECHOWSKI, Biblioteki naukowe Krakowa w okresie międzywojennym, Notes Biblioteczny (1) 1998, s. 33-62; idem, Biblioteki szkolne i oświatowe Krakowa w okresie międzywojennym, Notes Biblioteczny (1) 1999, s. 45-67.

230 Iwona KACZMAREK, Biblioteki oświatowe i publiczne w Lodzi w dwudziestoleciu międzywojennym, Acta Universitatis Lodziensis Folia Librorum (17) 2013, s. 75-95; eadem, Biblioteki szkolne w Łodzi w dwudziestoleciu międzywojennym. Przegląd działalności, Acta Universitatis Lodziensis Folia Librorum (20) 2015, s. 33-57. 
opracowania dokumentacyjne sporządzone pod kierunkiem B. Bieńkowskiej na temat kresów wschodnich II RP i terenów, które po 1944 roku znalazły się w granicach Polski ${ }^{231}$.

Problemy budownictwa i wyposażenia ${ }^{232}$, organizacji, finansowania i kadr, kształtowania się procesów bibliotecznych oraz roli bibliotek w systemie oświaty, nauce i kulturze II RP omawiano m.in. w rozprawach na temat poszczególnych typów bibliotek i pojedynczych placówek. Do takich należy artykuł Z. Gacy-Dąbrowskiej o bibliotekach naukowych ${ }^{233}$ i prace poświęcone poszczególnym placówkom tego typu, w tym Bibliotece Narodowej ${ }^{234}$, Śląskiej ${ }^{235}$, Jagiellońskiej ${ }^{236}$ czy Ministerstwa Wyznań Religijnych i Oświecenia Publicznego ${ }^{237}$. Z książnic ordynackich wyczerpującego studium doczekała się Biblioteka Ordynacji Krasińskich (Halina Tchórzewska-Kabata ${ }^{238}$ ). Ukazały się też monografia Biblioteki Państwowej im. Eustachego i Emilii Wróblewskich ${ }^{239}$ oraz ważne publikacje

231 Biblioteki na wschodnich ziemiach II Rzeczypospolitej. Informator. Red. nauk. Barbara Bieńkowska, oprac. Urszula Paszkiewicz et al., Poznań: Bogucki Wydawnictwo Naukowe 1998; Informator o stratach bibliotek i ksiegozbiorów domowych na terenach polskich okupowanych w latach 1939-1945 (bez ziem wschodnich). Red. nauk. B. Bieńkowska, oprac. U. Paszkiewicz, Janusz Szymański, Poznań: Bogucki Wydawnictwo Naukowe 2000.

232 M.in. A. BIRKENMAJER, Władysław SKOCZYLAS, Budownictwo i wyposażenie bibliotek. Materiały do nauki bibliotekarstwa, Wrocław: Uniwersytet Wrocławski 1958; Zbigniew CUDNIK, Skarbnice wiedzy. Studium budownictwa bibliotek, Wrocław: Zakład Narod. im. Ossolińskich 1980; Ewa POPŁAWSKA-BUKAŁO, Siedziba Biblioteki Publicznej m. st. Warszawy. Dzieje i architektura gmachu, Warszawa: Biblioteka Publiczna m. st. Warszawy, Biblioteka Główna Województwa Mazowieckiego 2006.

233 Z. GACA-DĄBROWSKA, Biblioteki i ich rola $w$ rozwoju życia naukowego $w$ Polsce (1919-1951), [w:] Historia nauki polskiej. T. 5: 1918-1951. Cz. 1. Pod red. Bogdana Suchodolskiego, red. tomu Zofia Skubała-Tokarska, Wrocław: Zakład Narod. im. Ossolińskich 1992, s. 569-603.

234 M.in. Danuta RYMSZA-ZALEWSKA, Stefan Demby. Znany i nieznany, Warszawa: Biblioteka Narodowa 2003.

${ }^{235}$ Barbara MARESZ, Źródła do dziejów Biblioteki Śląskiej w Archiwum Ossolineum (przechowywanym w Lwowskiej Naukowej Bibliotece im. W. Stefanyka), Katowice: Biblioteka Śląska 2008.

236 Jan BRZESKI, Środowisko Biblioteki Jagiellońskiej 1775-1939, Kraków: Biblioteka Jagiellońska 2014. Zob. też m.in. Andrzej CHWALBA, Collegium Maius, Kraków: Księgarnia Akademicka 2009, s. 77-130 (rozdział Collegium Maius jako biblioteka).

237 Jolanta DZIENIAKOWSKA, Biblioteki Ministerstwa Wyznań Religijnych i Oświecenia Publicznego (1917-1939), Roczniki Biblioteczne (51) 2007, s. 145-168.

238 H. TCHÓRZEWSKA-KABATA, Pod znakiem światta. Biblioteka Ordynacji Krasińskich 1844-1944, Warszawa: Biblioteka Narodowa 2010. Zob. też eadem, Droga do Okólnika....; K. AJEWSKI, Zbiory artystyczne Biblioteki i Muzeum Ordynacji Krasińskich w Warszawie, Warszawa: Neriton 2004.

239 H. ILGIEWICZ, Biblioteka Państwowa im. Eustachego i Emilii Wróblewskich w Wilnie (1912-1939) oraz towarzystwa ja popierajace, Toruń: Wydaw. Adam Marszałek 2015.

Roczniki Biblioteczne 60, 2016

(C) for this edition by CNS 
o Bibliotece Zakładu Ossolińskich ${ }^{240}$ i Kórnickiej ${ }^{241}$. Nowsze opracowania mają także biblioteki kościelne i zakonne ${ }^{242}$, wojskowe ${ }^{243}$, pedagogiczne (Jolanta Dzieniakowska ${ }^{244}$ ) oraz towarzystw naukowych i upowszechniających naukę (Grażyna Wrona ${ }^{245}$ ). Brakuje natomiast studiów na temat międzywojennych bibliotek ekonomicznych, rolniczych i technicznych.

Wśród bibliotek publicznych zarysy swoich dziejów mają niektóre większe i mniejsze książnice, np. w Warszawie ${ }^{246}$, Lublinie ${ }^{247}$ i Radomiu $^{248}$. Na uwagę zasługuje też piśmiennictwo poświęcone organizacjom społecznym prowadzącym działalność biblioteczną, takim jak m.in. Towarzystwo Czytelni Ludowych ${ }^{249}$,

240 M.in. K. KORZON, Ludwik Bernacki: bibliolog i edytor, Wrocław: Wydaw. Zakładu Narod. im. Ossolińskich 1974.

${ }^{241}$ M.in. Zbigniew KALISZ, Fundacja „Zaktady Kórnickie” na tle fundacji w 20-leciu międzywojennym, Pamiętnik Biblioteki Kórnickiej 1983, z. 20, s. 93-112.

242 Np. Edyta CHOMENTOWSKA, Zasób informacji w katalogach jezuickich z lat 19141939 (na podstawie zbiorów Biblioteki Uniwersyteckiej Katolickiego Uniwersytetu Lubelskiego Jana Pawła II), [w:] Narrata de fontibus hausta. Studia nad problematyka kościelna, polityczna $i$ archiwistyczna ofiarowane Janowi Skarbkowi w siedemdziesiata rocznice urodzin. Red. Anna Barańska, Witold Matwiejczyk, Lublin: Towarzystwo Naukowe Katolickiego Uniwersytetu Lubelskiego Jana Pawła II 2010, s. 917-936.

243 Józef Karol SŁUGOCKI, Biblioteki Polskiej Marynarki Wojennej w latach 1918-1939, Gdynia: Zespół Redakcyjno-Wydawniczy Marynarki Wojennej 2006. Z wcześniejszych publikacji zob. m.in. Eugenia Maria HORODYSKA, Centralna Biblioteka Wojskowa w latach 1919-1932 i jej rola w organizacji bibliotek wojskowych w Polsce, Warszawa: SBP 1966.

244 J. DZIENIAKOWSKA, Państwowe biblioteki dla nauczycieli w Drugiej Rzeczypospolitej. Studium historyczno-bibliologiczne, Kielce: Wydaw. Uniwersytetu Humanistyczno-Przyrodniczego Jana Kochanowskiego 2009. Zob. też eadem, Kuratoryjne biblioteki pedagogiczne na Kresach Wschodnich Drugiej Rzeczypospolitej. Wybór źródeł, Kielce: Kieleckie Towarzystwo Naukowe 2006.

245 G. WRONA, Towarzystwa naukowe w Krakowie w latach 1845-1939, Kraków: Wydaw. Naukowe Wyższej Szkoły Pedagogicznej 1994. Zob. też m.in. Hanna BOJCZUK, Z dziejów księgozbiorów polskich towarzystw lekarskich, Z Badań nad Polskimi Księgozbiorami Historycznymi (11) 1991, s. 175-193; Towarzystwa naukowe i upowszechniajace naukę działajace w przeszłości na ziemiach polskich. Cz. 1-3. Red. nauk. Barbara Sordylowa; oprac. zespół pod kier. Barbary Krajewskiej-Tartakowskiej, Wrocław: Zakład Narod. im. Ossolińskich; Warszawa: Biblioteka PAN 1990-1994.

246 M.in. Janina JAGIELSKA, Rola Biblioteki Publicznej m. st. Warszawy w polskim życiu bibliotecznym, [w:] Wokót bibliotekarstwa i bibliotek. Red. Jadwiga Sadowska, Warszawa: Wydaw. SBP 2005, s. 113-120; Marta PARNOWSKA, Generat Kazimierz Kardaszewicz. Lekarz, bibliotekarz, humanista, Warszawa: Biblioteka Publiczna m. st. Warszawy, Biblioteka Główna Województwa Mazowieckiego 2008. Z wcześniejszych publikacji zob. m.in. Irena GAWINKOWA, Biblioteka Publiczna w latach 1928-1939, [w:] Z dziejów książki i bibliotek w Warszawie..., s. 561-605.

247 Zdzisław BIELEŃ, Biblioteka Publiczna im. Hieronima Łopacińskiego od powstania do II wojny światowej, Bibliotekarz Lubelski (47) 2004, s. 7-42.

248 Halina ERDMAN, Miejska Biblioteka Publiczna w Radomiu w latach 1922-1939, Radom: Wojewódzka Biblioteka Publiczna 1982.

249 Witold JAKÓBCZYK, Towarzystwo Czytelni Ludowych 1880-1939, Poznań: Krajowa Agencja Wydawnicza 1982; Eugenia SŁAWIŃSKA, Kulturotwórcza rola Towarzystwa Czytelni 
Związek Młodzieży Wiejskiej RP „Wici”250, Towarzystwo Szkoły Ludowej251 i Polska Macierz Szkolna ${ }^{252}$. Należy odnotować postęp w badaniach nad rolą bibliotek w życiu mniejszości narodowych ${ }^{253}$. W 2012 roku ukazała się monografia Zdzisława Gębołysia o bibliotekarstwie niemieckim ${ }^{254}$.

Odnośnie do dziejów bibliotek domowych poza rozprawą Barbary Maresz o księgozbiorach lwowskich i kresowych znajdujących się w Bibliotece Śląskiej255 i studium Weroniki Pawłowicz o kolekcjach polskiego duchowieństwa katolickiego na Górnym Śląsku ${ }^{256}$ ukazało się wiele artykułów (przeważnie przyczynków) poświęconych księgozbiorom uczonych, literatów, działaczy społecznych i duchownych. Swoje opracowania mają także towarzystwa bibliofilskie, w tym krakowskie i wileńskie ${ }^{257}$.

Historia bibliotek polskich międzywojnia nie byłaby pełna bez badań dotyczących placówek funkcjonujących poza granicami kraju. Ogólne zarysy problematyki nakreślili jeszcze w latach 70. XX wieku Marian J. Lech i Janusz Albin ${ }^{258}$.

Ludowych na Pomorzu Gdańskim (1880-1939), Bydgoszcz: Wydaw. Uczelniane Wyższej Szkoły Pedagogicznej 1989; Grzegorz CHMIELEWSKI, Polskie biblioteki ludowe na pograniczu zachodnim $w$ rejonie babimojsko-międzyrzecko-skwierzyńskim w latach 1880-1939, Zielona Góra: Pro Libris 2002. Zob. też m.in. Barbara DĄBROWSKA, Ks. Antoni Ludwiczak (1878-1942). Zapalat światta w mroku, budzit życie polskie..., Poznań: Księgarnia Św. Wojciecha 1988.

250 Grażyna GZELLA, Biblioteki i czytelnictwo w kołach młodzieży wiejskiej CZMWi ZMW RP ,Wici” (1919-1928-1939), Toruń: Wydaw. Adam Marszałek 1991.

251 Maria Jolanta ŻMICHROWSKA, Towarzystwo Szkoły Ludowej (1891-1939), Olsztyn: Wyższa Szkoła Pedagogiczna 1992.

252 M.in. Krystyna WOJAKOWSKA, Działalność biblioteczna Polskiej Macierzy Szkolnej w Warszawie w latach 1906-1939. Zarys problematyki, Z Badań nad Polskimi Księgozbiorami Historycznymi (6) 1981, s. 73-108; Hanna MARKIEWICZ, Biblioteki Polskiej Macierzy Szkolnej 1918-1939, Przegląd Historyczno-Oświatowy 1984, nr 3, s. 267-286.

253 M.in. Marek ANDRZEJEWSKI, Biblioteki mniejszości narodowych w Polsce w okresie międzywojennym. Zarys problematyki, Roczniki Biblioteczne (31) 1987, z. 2, s. 85-108; Marta MEDUCKA, Biblioteki żydowskie w sieci bibliotecznej Drugiej Rzeczypospolitej, [w:] Rola mniejszości narodowych w kulturze i oświacie polskiej w latach 1700-1939. Pod red. Aleksandry Bilewicz i Stefanii Walasek, Wrocław: Wydaw. Uniwersytetu Wrocławskiego 1998, s. 255-267.

254 Zdzisław GĘBOŁYŚ, Biblioteki mniejszości niemieckiej w II Rzeczypospolitej, Katowice: Wydaw. Uniwersytetu Śląskiego 2012. Autor opisał tu też pokrótce biblioteki ukraińskie, białoruskie, litewskie, czeskie, rosyjskie i żydowskie, s. 413-433.

255 B. MARESZ, Ze Lwowa do Katowic. Przedwojenne ksiegozbiory lwowskie i kresowe w Bibliotece Śląskiej, Katowice: Biblioteka Śląska 2002.

256 Weronika PAWŁOWICZ, Księgozbiory polskiego duchowieństwa katolickiego na Górnym Śląsku w XIX i XX wieku (do 1939 r.), Katowice: Księgarnia św. Jacka 2009.

257 Barbara SZORNEL-DĄBROWSKA, Towarzystwo Miłośników Książki w Krakowie w latach 1922-1939, Kraków: Towarzystwo Miłośników Historii i Zabytków Krakowa 2001; Ewa ANDRYSIAK, Towarzystwo bibliofilów polskich w Wilnie 1926-1939, Kalisz: Kaliskie Towarzystwo Przyjaciół Nauk 2007.

258 M.J. LECH, Próby centralnej koordynacji akcji organizowania bibliotek polskich na emigracji (1929-1934), Problemy Polonii Zagranicznej (9) 1975, s. 119-130; Janusz ALBIN, Z dziejów 
Bibliotekarstwo polskie w ówczesnych Niemczech opisywali J. Wróblewski i Jerzy Ratajewski ${ }^{259}$. Jednak poza artykułem Jana Wróblewskiego na temat Litwy Kowieńskiej ${ }^{260}$ brakuje głębszych studiów nad dziejami polskiej książki i bibliotek w innych krajach ościennych, zwłaszcza w ZSRR i Czechosłowacji. Zarysy dziejów Biblioteki Polskiej w Paryżu przedstawili Irena Gałęzowska i w znacznie szerszym ujęciu — Franciszek Pułaski ${ }^{261}$. Ukazały się też m.in. artykuły zawierające ważne ustalenia o Bibliotece Muzeum Polski Współczesnej w Rapperswilu262.

Okres II wojny światowej w dziejach bibliotekarstwa polskiego ma bogatą literaturę. Bibliografia ważniejszych pozycji wydanych do 1993 roku, a dotyczących tylko strat wojennych, obejmuje ponad 900 publikacji ${ }^{263}$. Piśmiennictwo to wykorzystano, przygotowując raport Straty bibliotek w czasie II wojny światowej w granicach Polski z 1945 roku, opracowany przez B. Bieńkowską i zespół ${ }^{264}$. Raport zawierający jak dotąd najpełniejsze szacunkowe zestawienie strat wojennych stanowił punkt wyjścia do rozbudowanych studiów, takich jak np. rozprawy o bibliotekach krakowskich Piotra Lechowskiego i warszawskich A. Mężyńskie$\mathrm{go}^{265}$. Niezbędny jest też rozwój badań nad bibliotekarstwem kresów wschodnich — przykładem mogą być rozprawy Macieja Matwijówa poświęcone bibliotekom lwowskim $^{266}$. Na pełne opracowanie czekają też wojenne losy bibliotek mniej-

bibliotek i książki polskiej za granica w latach 1919-1939, Roczniki Biblioteczne (21) 1977, z. 1/2, s. $305-368$.

259 J. WRÓBLEWSKI, Biblioteki polskie na Warmii, Mazurach i Powiślu w latach 18811939, Olsztyn: Wydaw. Pojezierze 1968; idem, Polskie biblioteki ludowe; Jerzy RATAJEWSKI, Ruch czytelniczy i biblioteki polskie na Śląsku Opolskim 1922-1939 w świetle niektórych materiałów archiwalnych i prasowych, Opole: Instytut Śląski w Opolu 1970.

260 J. WRÓBLEWSKI, Z dziejów książki polskiej na Litwie Kowieńskiej w okresie międzywojennym, Roczniki Biblioteczne (31) 1987, z. 2, s. 109-149.

261 Irena GAŁĘZOWSKA, Bibliothèque Polonaise de Paris 1839-1939, Paris: [s.n.] 1946; Franciszek PUŁASKI, Biblioteka Polska w Paryżu 1893-1948, Paryż: [s.n.] 1948.

262 Wojciech KANTAK, Działalność biblioteki Muzeum Polski Współczesnej w Rapperswilu w latach 1936-1945, Acta Universitatis Nicolai Copernici Bibliologia (2/3) 1998, s. 197-218; S. CHANKOWSKI, Muzeum Polski Współczesnej w Rapperswilu w latach 1936-1939, Rocznik Biblioteki Narodowej (32) 1998, s. 281-326; Elżbieta JASTRZĘBOWSKA, Drugi Rapperswil i jego kustosz, Rocznik Biblioteki Narodowej (36) 2004, s. 275-298.

263 J. PUCHALSKI, Literatura przedmiotu z lat 1939-1949 na temat losów bibliotek w czasie okupacji niemieckiej, Z Badań nad Polskimi Księgozbiorami Historycznymi (Tom specjalny) 2004, s. $149-159$.

264 B. BIEŃKOWSKA et al., Straty bibliotek w czasie II wojny światowej w granicach Polski z 1945 roku. Wstępny raport o stanie wiedzy. Cz. 1. Analiza. Cz. 2. Tablice. Red. nauk. A. Mężyński, Warszawa: Wydaw. Reklama - Wojciech Wójcicki 1994.

265 P. LECHOWSKI, Biblioteki Krakowa w okresie okupacji niemieckiej 1939-1945, Kraków: Polskie Towarzystwo Bibliologiczne 1999; A. MĘŻYŃSKI, Biblioteki Warszawy w latach 1939-1945, Warszawa: Ministerstwo Kultury i Dziedzictwa Narodowego 2010.

266 Maciej MATWIJÓW, Walka o lwowskie dobra kultury w latach 1945-1948, Wrocław: Towarzystwo Przyjaciół Ossolineum 1996; idem, Zakład Narodowy imienia Ossolińskich w latach 1939-1946, Wrocław: Towarzystwo Przyjaciół Ossolineum 2003. 
szości narodowych oraz powojenne tzw. zbiorów „zabezpieczonych”267, w tym poniemieckich $^{268}$ i podworskich ${ }^{269}$. Zagadnienia te łączą się m.in. z problematyką restytucji dóbr kultury, będącą przedmiotem studiów Dariusza Matelskiego i innych badaczy ${ }^{270}$.

W pracach nad historią bibliotek polskich na obczyźnie w czasie i zaraz po II wojnie światowej ${ }^{271}$ może być pomocny informator Biblioteki polskie poza krajem w latach 1938-1948 272 . Problematyka ta wymaga bowiem szczegółowych badań ${ }^{273}$, o czym świadczy rozprawa Agnieszki Łakomy m.in. na temat działalności bibliotek polskich w Niemczech Zachodnich w latach 1945-1950274.

Pomimo że w okresie PRL ukazało się wiele ważnych wydawnictw zbiorowych, zarysów i prac monograficznych zawierających m.in. treści z zakresu historii najnowszej bibliotek i bibliotekarstwa — np. Jana Trzynadlowskiego, H. Wię-

267 Ryszard NOWICKI, Działalność Aleksandra Birkenmajera na rzecz ochrony zbiorów bibliotecznych. Ziemie zachodniej i pótnocnej Polski w latach 1945-1947, Poznań: Biblioteka Uniwersytecka 2006; idem, Rola katowickiej Zbiornicy Księgozbiorów Zabezpieczonych w powojennej ochronie zbiorów bibliotecznych w Polsce, Bydgoszcz: Wydaw. Uniwersytetu Kazimierza Wielkiego 2015. Zob. też m.in. P. BUCHWALD-PELCOWA, Powojenne wędrówki starych druków w Polsce, [w:] Symposia bibliologica..., s. 151-159; J. PLIS, Ksiegozbiory rozproszone. Problemy prawne i biblioteczne, Archiwa, Biblioteki i Muzea Kościelne (66) 1996, s. 405-445; H. ŁASKARZEWSKA, Zbiory przejęte i przemieszczone w bibliotekach polskich po drugiej wojnie światowej. Problemy własności, przykłady rozwiązan, [w:] Własność a dobra kultury. Pod red. Grażyny Czubek i Piotra Kosiewskiego, Warszawa: Fundacja im. Stefana Batorego 2006, s. 15-47.

268 Z. GĘBOŁYŚ, Losy księgozbiorów niemieckich w Polsce po II wojnie światowej. Rekonesans badawczy, [w:] Księgozbiory rozproszone. Losy księgozbiorów historycznych po II wojnie światowej. Materiaty z konferencji naukowej zorganizowanej przez Muzeum Zamkowe w Malborku 19 października 2012 roku. Red. Aleksandra Siuciak, Malbork: Muzeum Zamkowe 2015, s. $157-172$.

269 Stefan IWANIAK, Ziemiańskie dobra kulturowe w województwie kieleckim (1944-1946), Kielce: Wyższa Szkoła Pedagogiczna 1996. Zob. też m.in. Adam F. BARAN, Bibliotekarz Dzikowa. Dr Michat Marczak (1886-1945), Sandomierz: Wydaw. Diecezjalne 1996; J.M. MARSZALSKA, Biblioteka i archiwum Sanguszków. Zarys dziejów, Tarnów: Tarnowskie Towarzystwo Kulturalne 2000.

270 Dariusz MATELSKI, Losy polskich dóbr kultury w Rosji i ZSRR. Próby restytucji: archiwa - księgozbiory - dzieła sztuki - pomniki, Poznań: Inter-Arpress 2003; idem, Grabież i restytucja polskich dóbr kultury. Od czasów nowożytnych do wspótczesnych, T. 1-2. Kraków: Towarzystwo Przyjaciół Sztuk Pięknych 2006.

271 Zob. np. O.S. CZARNIK, W drodze do utraconej Itaki. Prasa, książi i czytelnictwo na szlaku Samodzielnej Brygady Strzelców Karpackich (1940-1942) oraz Armii Polskiej na Wschodzie i 2. Korpusu (1941-1946),Warszawa: Biblioteka Narodowa 2012.

272 Biblioteki polskie poza krajem w latach 1938-1948. Informator. Red. nauk. Barbara Bieńkowska, oprac. Urszula Paszkiewicz, Janusz Szymański, Poznań: Bogucki Wydawnictwo Naukowe 2005.

273 B. BIEŃKOWSKA, Dziesięć lat z życia bibliotek polonijnych (1938-1948), Z Badań nad Polskimi Księgozbiorami Historycznymi (20) 2002, s. 79-88.

274 Agnieszka ŁAKOMY, Polska książka na obczyźnie. Niemcy Zachodnie 1945-1950, Warszawa: Wydaw. SBP 2011.

Roczniki Biblioteczne 60, 2016

(C) for this edition by CNS 
ckowskiej, Leona Łosia i J. Ry1 ${ }^{275}$ — skupię się tutaj na pracach opublikowanych po 1989 roku.

Tak jak w przeszłości, również w ostatnim dwudziestopięcioleciu zajmowano się odbudową, organizacją i działalnością bibliotekarstwa w latach 1944-1948, zwłaszcza publicznego ${ }^{276}$. Usunięcie Józefa Grycza z funkcji naczelnego dyrektora bibliotek i likwidacja Państwowego Instytutu Książki (pisała o tym Małgorzata Korczyńska-Derkacz) ${ }^{277}$ symbolicznie zapoczątkowały okres ,stalinowskich deformacji w polskim bibliotekarstwie", jak to określił A. Mężyński ${ }^{278}$. Wśród publikacji poświęconych tej tematyce do najważniejszych należy Papierowa rewolucja Stanisława Adama Kondka ${ }^{279}$. Ukazały się też wydawnictwa źródłowe i szczegółowe prace o cenzurze bibliotecznej i ideologicznym „oczyszczaniu” zbiorów (m.in. Zbigniewa Żmigrodzkiego, Andrzeja Dróżdża, Marty Nadolnej-Tłuczykont) ${ }^{280}$. Jednak wypełnienie wszystkich „białych plam” w historiografii polskiego bibliotekarstwa lat powojennych wymaga dalszych studiów.

275 Jan TRZYNADLOWSKI, Zakład Narodowy im. Ossolińskich 1817-1967. Zarys dziejów, Wrocław: Zakład Narod. im. Ossolińskich. Wydawnictwo 1967; Leon ŁOŚ, Biblioteki Polskiej Akademii Nauk. Zarys kształtowania sieci i stan aktualny, Wrocław: Zakład Narod. im. Ossolińskich. Wydawnictwo 1973; H. WIECKOWSKA, Akademickie ksztatcenie bibliotekarzy. Zarys historyczny, Warszawa: Wydaw. Akcydensowe 1979; J. RYŁ, Biblioteka Katedralna w Gnieźnie w latach 1650-1975, Archiwa, Biblioteki i Muzea Kościelne (51) 1985, s. 117-281. Zob. też m.in. 50 lat Biblioteki Narodowej, Warszawa 1928-1978, red. Witold Stankiewicz et al., Warszawa: Biblioteka Narodowa 1984.

276 M.in. Pótwiecze Dekretu o bibliotekach i opiece nad zbiorami bibliotecznymi. Refleksje i opinie bibliotekarzy. Materiaty ze spotkania ,okragłego stołu” Warszawa, 17 kwietnia 1996 r. Red. Lucjan Biliński, Warszawa: Centrum Ustawicznego Kształcenia Bibliotekarzy 1996; J. PUCHALSKI, Prace Józefa Grycza nad organizacją bibliotekarstwa publicznego w latach 1945 1949, Z Badań nad Książką i Księgozbiorami Historycznymi Część I (5) 2011, s. 53-88; Część II (6) 2012, s. 79-112; P. LECHOWSKI, Problemy i organizacja powszechnego bibliotekarstwa publicznego w Polsce w latach 1945-1951, Roczniki Biblioteczne (55) 2011, s. 91-112.

277 Małgorzata KORCZYŃSKA-DERKACZ, Państwowy Instytut Ksiażki (1946-1949) i jego rola $w$ rozwoju bibliologii, bibliotekarstwa i kultury ksiązki w Polsce, Wrocław: Wydaw. Uniwersytetu Wrocławskiego 2011.

278 A. MĘŻYŃSKI, Bibliotekarstwo polskie w latach 1948-1956. Kłopoty historyków (w 1990 r.), Poradnik Bibliotekarza 1990, nr 1/3, s. 19-23.

279 S.A. KONDEK, Papierowa rewolucja, Warszawa: Biblioteka Narodowa 1999.

280 Cenzura PRL. Wykaz ksiażek podlegajacych niezwłocznemu wycofaniu 1 X 1951, posł. Z. Żmigrodzki, Wrocław: Nortom 2002; Andrzej DRÓŻDŻ, Książka w świecie utopii, Kraków: Wydaw. Naukowe Akademii Pedagogicznej 2006; Marta NADOLNA-TŁUCZYKONT, Powrót książek ,zakazanych” do wspótczesnych odbiorców (wybrane zagadnienia), Katowice: Wydaw. Uniwersytetu Śląskiego 2013. Zob. też m.in. Mirosław A. SUPRUNIUK, Dokument o paleniu ksiażek A.D. 1955, Acta Universitatis Nicolai Copernici Bibliologia (4) 2000, s. 159-176; J. DŁUGOSZ, Akcja niszczenia przedwojennych ksiażek polskich w bibliotekach publicznych (1951-1955), Forum Naukowe (1) 2001, s. 215-284; Janusz DUNIN, Igor KLUCZNY, Biblioteki naukowe wobec cenzury, Przegląd Biblioteczny 2001, z. 4, s. 328-346; Krzysztof BIELAWNY, Cenzura i kontrola księgozbiorów religijnych $w$ diecezji warmińskiej w okresie PRL-u, Studia Elbląskie (8) 2007, s. 47-63; Teresa GÓRNIAK, Barbara SALETRA, Cenzura w polskich bibliotekach naukowych 
Zapewne przyczynią się do tego opracowania na temat dziejów bibliotek w poszczególnych regionach ${ }^{281}$ i miejscowościach ${ }^{282}$. Działalność bibliotek publicznych i jej uwarunkowania w PRL opisywali Jadwiga Kołodziejska ${ }^{283}$ i Jerzy $\mathrm{Maj}^{284}$, a Jacek Puchalski zarysował ostatnio dzieje bibliotekarstwa naukowe$\mathrm{go}^{285}$. Stosunkowo liczne są opracowania na temat bibliotek szkolnych i pedagogicznych (m.in. M. Drzewiecki) ${ }^{286}$. Problematykę bibliotek więziennych podejmowała natomiast Barbara Elżbieta Zybert ${ }^{287}$.

Odnośnie do historii poszczególnych placówek najwięcej publikacji dotyczy bibliotek publicznych różnej wielkości i rangi, w tym wojewódzkich i miejskich w Warszawie, Łodzi, Lublinie i Zamościu ${ }^{288}$. Z bibliotek naukowych po 1989 roku

w latach 1945-1989 na przykładzie Biblioteki Uniwersytetu Łódzkiego, [w:] Nie po myśli władzy. Studia nad cenzura i zakresem wolności słowa na ziemiach polskich od wieku XIX do czasów współczesnych. Pod red. Doroty Degen i Marcina Żyndy, Toruń: Wydaw. Naukowe Uniwersytetu Mikołaja Kopernika 2012, s. 263-279.

281 Np. Marzena KOWALCZUK, Biblioteki publiczne na Podlasiu w XVIII-XX wieku, Siedlce: Stowarzyszenie tutaj teraz 2008. Zob. też m.in. Książka na Ślasku w latach 1945-1956. Zarys problematyki. Pod red. Marii Pawłowiczowej, Katowice: Śląsk 1997; Książka na Śląsku w latach 1956-1989. Zarys problematyki. Pod red. M. Pawłowiczowej, Katowice: Śląsk 1999.

282 Np. Grażyna GULIŃSKA, Biblioteki publiczne, szkolne i pedagogiczne w Kielcach w latach 1945-1975, Kielce: Wyższa Szkoła Pedagogiczna im. Jana Kochanowskiego 1992; J. DUNIN, Moja Łódź petna książek. O kulturze książi ze źródeł $i$ wspomnień, Łódź: Łódzka Księgarnia Niezależna 2002; Zbigniew ŁUCZAK, Dzieje bibliotek w Sieradzu od powstania miasta do końca XX wieku, Sieradz: Miejska Biblioteka Publiczna 2007. Zob. też m.in. Z dziejów bibliotek przemyskich. Praca zbiorowa z okazji sześćdziesięciolecia Przemyskiej Biblioteki Publicznej (1947-2007). Pod red. Anny Siciak, Przemyśl: Przemyska Biblioteka Publiczna im. Ignacego Krasickiego 2009.

283 M.in. J. KOŁODZIEJSKA, Kultura, gospodarka, biblioteki, Warszawa: Biblioteka Narodowa 1992.

284 Jerzy MAJ, Biblioteki publiczne 1945-1990 na tle innych instytucji kultury, Warszawa: Biblioteka Narodowa 1996.

285 J. PUCHALSKI, Biblioteki w życiu naukowym PRL i poza krajem w latach 1939-1989, [w:] Historia nauki polskiej. T. X: 1944-1989. Część II: Instytucje. Pod red. Leszka Zasztowta i Joanny Schiller-Walickiej, Warszawa: Instytut Historii Nauki PAN 2015, s. 359-470.

286 M. DRZEWIECKI, Biblioteki szkolne i pedagogiczne w Polsce. Rola w procesie dydaktycznym i miejsce w krajowej sieci biblioteczno-informacyjnej, Warszawa: Wydaw. Uniwersytetu Warszawskiego 1991; zob. też m.in. Funkcjonowanie bibliotek szkolnych w Polsce (w latach 1945 1989). Pod red. Jerzego Jarowieckiego, Kraków: Wydaw. Naukowe Wyższej Szkoły Pedagogicznej im. Komisji Edukacji Narodowej w Krakowie 1991.

287 E.B. ZYBERT, Biblioteki więzienne. Zarys problematyki, Warszawa: SBP 1991.

288 Np. 75 lat Ksiażnicy Miejskiej w Łodzi. Materiaty z sesji poświęconej 75 rocznicy powstania Wojewódzkiej i Miejskiej Biblioteki Publicznej im. Marszałka Józefa Pitsudskiego w Łodzi 4 grudnia 1992 r. Pod red. Elżbiety Pawlickiej i Andrzeja Kempy, Łódź: Wojewódzka i Miejska Biblioteka Publiczna 1995; Regina PAŁCZYŃSKA, Wojewódzka i Miejska Biblioteka Publiczna w Zamościu 1921-1996, Zamość: Wojewódzka i Miejska Biblioteka Publiczna 1996; Biblioteka na Koszykowej 1907-1997. Zbiór prac poświęconych Bibliotece Publicznej m. st. Warszawy - Bibliotece Głównej. Red. Marta Parnowska et al., Warszawa: Biblioteka Publiczna m. st. Warszawy — Biblioteka Główna 1999; Z. BIELEŃ, Wojewódzka Biblioteka Publiczna w Lublinie w latach 
szersze opracowania poświęcono Bibliotece Narodowej289 oraz niektórym bibliotekom uczelnianym: Uniwersyteckiej we Wrocławiu, Uniwersyteckiej w Warszawie, Uniwersytetu Jana Kochanowskiego w Kielcach, Politechniki Łódzkiej i Politechniki Wrocławskiej ${ }^{290}$. Z placówek PAN i towarzystw naukowych nowsze opracowania mają Muzeum Czartoryskich ${ }^{291}$, Biblioteka Gdańska ${ }^{292}$ i Biblioteka Towarzystwa Naukowego Płockiego ${ }^{293}$, a z urzędów centralnych - Biblioteka Głównego Urzędu Statystycznego ${ }^{294}$. Punktem wyjścia do nowego opracowania historii Centralnej Biblioteki Wojskowej może być jej kalendarium ${ }^{295}$. Z okazji jubileuszy wydano w ostatnich latach kilka publikacji na temat dziejów wojewódzkich bibliotek pedagogicznych, m.in. lubelskiej, opolskiej i kieleckiej ${ }^{296}$. Z dorob-

1950-1955, Bibliotekarz Lubelski 2002, s. 3-46; idem, Od WiMBP do WiMBP, czyli dzieje Biblioteki im. Hieronima Łopacińskiego w latach 1955-2001. Cz. 1. Lata 1955-1975. Cz. II. Lata 1976-2001, Bibliotekarz Lubelski (51-52) 2008-2009, s. 7-84.

289 A. KŁOSSOWSKI, Biblioteka Narodowa w Warszawie. Zbiory i działalność, Warszawa: Biblioteka Narodowa 1990.

290 Jan OŻÓG, Zarys historii Biblioteki Uniwersyteckiej we Wrocławiu, Wrocław: Wydaw. Uniwersytetu Wrocławskiego 1995; Biblioteka Uniwersytecka w Warszawie w latach 1945-1980. Pod red. nauk. Andrzeja Mężyńskiego przy współpr. Anny Bednarz, Warszawa: Wydaw. Uniwersytetu Warszawskiego 1998; Z dziejów Biblioteki Głównej Uniwersytetu Humanistyczno-Przyrodniczego Jana Kochanowskiego w Kielcach 1969-2008. Pod red. Henryka Suchojada, Kielce: Biblioteka Główna Uniwersytetu Humanistyczno-Przyrodniczego Jana Kochanowskiego 2009; Czesława GARNYSZ, Biblioteka Politechniki Łódzkiej. Ponad 60 lat historii, Łódź: Biblioteka Politechniki Łódzkiej 2009; Biblioteka Politechniki Wrocławskiej 1946-2011. Historia, działalność, organizacja. Red. Henryk Szarski, Jadwiga Wojtczak, Wrocław: Oficyna Wydawnicza Politechniki Wrocławskiej 2011.

291 Zdzisław ŻYGULSKI jun., Adam ZAMOYSKI, Marek ROSTWOROWSKI, Muzeum Czartoryskich. Historia i zbiory, Kraków: Muzeum Narodowe 1998. Zob. też m.in. Janusz NOWAK, Ordynacja sieniawska książat Czartoryskich. Plany — zamierzenia — realizacja, Roczniki Biblioteki PAU i PAN w Krakowie 45 (2000), s. 121-159.

292 Bibliotheca Senatus Gedanensis 1596-1996. Dzieje i zbiory. Praca zbiorowa pod red. Marii Babnis i Zbigniewa Nowaka, Gdańsk: Wydaw. Gdańskie 1998.

293 Anna Maria STOGOWSKA, Dzieje i funkcje Biblioteki Towarzystwa Naukowego Płockiego (1820-1985), Płock: Wydaw. Towarzystwa Opieki nad Zabytkami Oddział w Płocku 1994. 294 Bożena ŁAZOWSKA, 90 lat Biblioteki GUS w stużbie statystyki polskiej-misja, ludzie, zadania, Warszawa: Centralna Biblioteka Statystyczna im. Stefana Szulca 2009.

295 Anna GĄSIOROWSKA, Magdalena LEWNAU, Krystyna PIWOWARSKA, Centralna Biblioteka Wojskowa 1919-1999. Kalendarium, Warszawa: Centralna Biblioteka Wojskowa, Oficyna Wydawnicza Rytm 1999. Zob. też K. PIWOWARSKA, Zarys historii Centralnej Biblioteki Wojskowej im. Marszałka Józefa Pitsudskiego, Kwartalnik Bellona (3) 2009, s. 9-36.

296 Nauczycielska książnica. 80 lat Pedagogicznej Biblioteki Wojewódzkiej im. Komisji Edukacji Narodowej w Lublinie 1927-2007. Opracowanie zbiorowe pod red. Haliny Kołodziejczyk, Grażyny Kłos, Anety Głowackiej, Lublin: Polihymnia 2008; Pedagogiczna Biblioteka Wojewódzka w Opolu. Historia i współczesność (1951-2011). Red. Anna Zacłona, Opole: Pedagogiczna Biblioteka Wojewódzka 2011; 70 lat Pedagogicznej Biblioteki Wojewódzkiej w Kielcach 1945-2015. Pod redakcją Marka Lisa, Kielce: Pedagogiczna Biblioteka Wojewódzka 2015. 
ku historiografii bibliotek kościelnych ostatnich lat należy wymienić monografie Biblioteki Kapituły Włocławskiej297 i Biblioteki Seminaryjnej w Pelplinie ${ }^{298}$.

Na przyszły, syntetyczny obraz dziejów bibliotekarstwa w PRL powinny się też złożyć opracowania na temat bibliotek grup etnicznych i wyznaniowych. Badania takie podjęła m.in. Zoja Jaroszewicz-Pieresławcew ${ }^{299}$. Dogłębniejszego zbadania wymaga ponadto prywatne kolekcjonerstwo i ruch bibliofilski ${ }^{300}$. Brakuje też współczesnych studiów dotyczących m.in. kształtowania się prawa bibliotecznego w Polsce Ludowej i jego wpływu na funkcjonowanie bibliotekarstwa ${ }^{301}$, procesów bibliotecznych ${ }^{302}$, pragmatyki i statusu zawodowego bibliotekarzy oraz środowiska bibliotekarskiego ${ }^{303}$. W przypadku ostatniego bloku zagadnień wiedzę poszerzają opracowania biograficzne ${ }^{304}$, informatory ze Stownikiem pracowników

297 Bernadeta IWAŃSKA-CIEŚLIK, Biblioteka kapituły katedralnej we Włocławku, Bydgoszcz: Wydaw. Uniwersytetu Kazimierza Wielkiego 2013. Zob. też m.in. Stanisław CHODYŃSKI, Biblioteka Kapituły Włocławskiej. Uzupełnił rozdziałem o katalogach i wydał Stanisław Librowski, Kronika Diecezji Włocławskiej (43) 1949 nr 9-12, s. 173-280; (44) 1950 nr 1/2, s. 33-66.

298 Barbara GÓRA, Biblioteka Wyższego Seminarium Duchownego w Pelplinie 1828-2000, Kraków: Akademia Pedagogiczna im. Komisji Edukacji Narodowej w Krakowie 2007.

299 Z. JAROSZEWICZ-PIERESŁAWCEW, Starowiercy w Polsce i ich księgi, Olsztyn: Ośrodek Badań Naukowych im. Wojciecha Kętrzyńskiego 1995. Zob. też m.in. Renata ŚWIDER, Adrian ULJASZ, Biblioteka dla każdego. Misja, historia, współczesność, Skoczów: Parafia Ewangelicko-Augsburska 2014; Nawojka CIEŚLIŃSKA-LOBKOWICZ, Judaika i zbiory judaików w Polsce od przedwojnia po dzień dzisiejszy. Zarys problematyki, Kwartalnik Historii Żydów 2011 nr 2, s. 211-249.

300 Temat ten podjęli m.in. Cecylia, Janusz DUNINOWIE, Philobiblon polski, Wrocław: Ossolineum 1983; Janusz KAPUŚCIK, W kręgu lekarzy, uczonych i bibliofilów, Warszawa: Główna Biblioteka Lekarska 1993.

301 Zarys problematyki przedstawił cytowany już T. Zarzębski, Polskie prawo biblioteczne..., s. 31-62 (rozdział Polskie prawo biblioteczne w PRL) oraz s. 105-271 (katalog aktów normatywnych).

302 Np. Ewolucja procesów bibliotecznych na tle dziejów Biblioteki Głównej Akademii Ekonomicznej we Wrocławiu. Pod red. Barbary Żmigrodzkiej, Wrocław: Wydaw. Akademii Ekonomicznej im. Oskara Langego 2007. Zob. też m.in. Ewa DĄBROWSKA, Polityka państwa wobec bibliotek $w$ dziedzinie importu zachodnich ksiażek naukowych $w$ latach 1945-1990, Roczniki Biblioteczne (43) 1999, s. 55-68; Agnieszka ŁUSZPAK, Katalogi rzeczowe w stużbie ideologii (na przykładzie Biblioteki Uniwersyteckiej we Wrocławiu w latach pięćdziesiątych XX wieku), [w:] Nie po myśli władzy..., s. 263-279.

303 Np. Wiesława GMITEREK, Bibliotekarze dyplomowani - wczoraj, dziś i jutro, [w:] Biblioteki naukowe w kulturze i cywilizacji. Działania i codzienność. T. 1. Poznań, 15-17 czerwca 2005, materiaty konferencyjne. Pod red. Haliny Ganińskiej, Poznań: Biblioteka Główna Politechniki Poznańskiej 2005, s. 291-302; M. KORCZYŃSKA-DERKACZ, Ewolucja wizerunku i roli społeczno-zawodowej bibliotekarza — od okresu międzywojennego po lata pięćdziesiate XX w. Przeglad stanowisk, Zarządzanie Biblioteką. Library Management 2013 nr 1 (5), s. 76-84.

304 M.in. Twórcy nowoczesnego bibliotekarstwa polskiego. Red. Bronisław Kocowski, Wrocław: Zakład Narod. im. Ossolińskich, Wydaw. PAN 1974; Portrety bibliotekarzy polskich. Red. Irena Morsztynkiewiczowa, Wrocław: Zakład Narod. im. Ossolińskich, Wydaw. PAN 1980; 
książki polskiej ${ }^{305}$ i publikacje pamiętnikarskie ${ }^{306}$. Trzeba przy tym zaznaczyć, że wielość publikacji na temat poszczególnych postaci nie zawsze składa się na całość ukazującą pełny kontekst ich osobowości, działalności i znaczenia. Na swoich biografów czekają zatem m.in. A. Birkenmajer, E. Kuntze, M. Łodyński, J. Baumgart i wielu innych współtwórców nowoczesnego bibliotekarstwa polskiego. Brakuje również opracowania dziejów Stowarzyszenia Bibliotekarzy Polskich ${ }^{307}$. Na zbadanie zasługuje też rola czasopiśmiennictwa dziedzinowego w kształtowaniu się teorii i praktyki bibliotekarstwa w Polsce ${ }^{308}$.

Krótki zarys powojennych dziejów bibliotek polskich na obczyźnie opublikował A. Kłossowski ${ }^{309}$. Ich działalność w Wielkiej Brytanii opisały Maria Da-

Adam Lysakowski - bibliotekarz, bibliograf, bibliolog. Materiaty z sesji jubileuszowej, Warszawa, 10 września 2002. Red. Lidia Paluszkiewicz-Horubała, Warszawa: Biblioteka Narodowa 2003; Helena Hleb-Koszańska - bibliotekarz i bibliograf. Materiaty z sesji jubileuszowej w 100. rocznice urodzin, Warszawa, 10 czerwca 2003. Red. Agnieszka Konopka, Warszawa: Biblioteka Narodowa 2003; Maria Dembowska. W kręgu bibliografii, bibliotekarstwa i informacji naukowej. Księga jubileuszowa w 70-lecie pracy zawodowej. Pod red. Jadwigi Sadowskiej, Warszawa: Biblioteka Narodowa 2007; Jan SANDECKI, Stefan Vrtel-Wierczyński. W kręgu bibliografii i bibliotekarstwa, Warszawa: Wydaw. SBP 2007; Jan Muszkowski - ludzie, epoka, ksiażki. Tradycje i kontynuacje. Red. nauk. Grzegorz Czapnik, Zbigniew Gruszka, Jacek Ladorucki, Łódź: Wydaw. Uniwersytetu Łódzkiego; Warszawa: Wydaw. SBP 2014; Helena Więckowska. Bibliotekarz, historyk, bibliolog. Pod red. Jadwigi Koniecznej i Magdaleny Rzadkowolskiej, Łódź: Wydaw. Uniwersytetu Łódzkiego 2015.

305 Słownik pracowników ksiązki polskiej. Pod red. Ireny Treichel, Warszawa; Łódź: Państwowe Wydawnictwo Naukowe 1972, wraz z suplementami pod red. I. Treichel (1986) i Hanny Tadeusiewicz (2000 i 2010). Zob. też m.in. Słownik bibliotekarzy wielkopolskich 1918-2000. Pod red. Franciszka Łozowskiego, Poznań: Wojewódzka Biblioteka Publiczna: Centrum Animacji Kultury [2001].

306 Portrety ossolińskie. Antologia wspomnień. Oprac. Eugeniusz Adamczak, Wrocław: Zakład Narod. im. Ossolińskich 1992; Wspóttwórcy bibliotekarstwa polskiego. Wywiady i wspomnienia z lat 1979-1998. Oprac. Barbara Sordylowa, Warszawa: Biblioteka Polskiej Akademii Nauk w Warszawie 2002; Żyja w naszej pamięci - wspomnienia o pracownikach Biblioteki Publicznej m. st. Warszawy. Red. Janina Jagielska, Teresa Jedynak, Warszawa: Biblioteka Publiczna m. st. Warszawy — Biblioteka Główna Województwa Mazowieckiego 2006; 13 tomów z lat 1991-2015 wydanych w serii „Bibliotekarze Polscy we Wspomnieniach Współczesnych”, zob. Jadwiga SADOWSKA, Bibliotekarze we wspomnieniach Zespołu Historyczno-Pamiętnikarskiego SBP, Bibliotekarz $2014 \mathrm{nr}$ 5, s. 12-16.

307 Z publikacji z ostatnich lat zob. m.in. Kronika Stowarzyszenia Bibliotekarzy Polskich 1917-2007. Oprac. Andrzej Kempa, Warszawa: Wydaw. SBP 2007.

308 Należy odnotować ukazanie się opracowania Zbigniewa GRUSZKI, „Przegląd Biblioteczny”. Monografia, Łódź: Wydaw. Uniwersytetu Łódzkiego; Warszawa: Wydaw. SBP 2012.

309 A. KŁOSSOWSKI, Biblioteki polskie na obczyźnie, Warszawa: Biblioteka Narodowa 1992; idem, Instytucje książki polskiej i księgozbiory polskie na obczyźnie. Początki - cele, zadania i przyczyny przemian - wspótczesne przeobrażenia i perspektywy, Acta Universitatis Nicolai Copernici Bibliologia (2/3) 2000, s. 89-141. Zob. też m.in. Muzea, biblioteki i archiwa polskie na Zachodzie. Praca zbiorowa pod red. Hieronima Fokcińskiego et al., oprac. Bolesław Bokszczanin et al., Londyn: Stała Konferencja Muzeów, Bibliotek i Archiwów Polskich na Zachodzie 1991;

Roczniki Biblioteczne 60, 2016

(C) for this edition by CNS 
nilewicz-Zielińska i Jadwiga Szmidt ${ }^{310}$. Opublikowane dotąd piśmiennictwo na temat pozostałych krajów, regionów, miejscowości czy działalności bibliotecznej poszczególnych organizacji emigracyjnych i polonijnych może stanowić punkt wyjścia do przyszłych, szczegółowych badań ${ }^{311}$. Najlepiej rozpoznane są dzieje i zbiory biblioteczne instytucji, które w 1979 roku zawiązały Stałą Konferencję Muzeów, Archiwów, Bibliotek Polskich na Zachodzie (pod tą nazwą od 1986 roku) ${ }^{312}$, a zwłaszcza Biblioteki Polskiej w Paryżu ${ }^{313}$, Biblioteki Polskiej w Londynie ${ }^{314}$, Archiwów, Bibliotek i Muzeów Polonii w Orchard Lake ${ }^{315}$, Muzeum Polskiego w Ameryce ${ }^{316}$, Muzeum Polskiego w Rapperswilu ${ }^{317}$, Polskiego Instytutu Nauko-

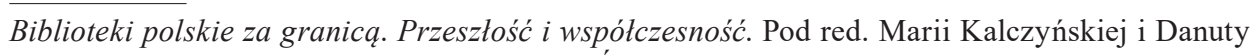
Sieradzkiej, Katowice: Wydaw. Uniwersytetu Śląskiego 2007.

310 Maria DANILEWICZ-ZIELIŃSKA, Książk i czytelnictwo polskie w Wielkiej Brytanii. Szkice, Warszawa: Biblioteka Narodowa 1996; Jadwiga SZMIDT, Biblioteki polskie we współczesnym Londynie, Warszawa: Wydaw. SBP 1998.

311 Np. Andrzej BROŻEK, Polskie biblioteki ludowe na emigracji, Biuletyn Biblioteki Jagiellońskiej (34/35) 1984/1985, s. 163-198; J. WRÓBLEWSKI, Rola ksiązki polskiej w działalności Związu Polaków w Niemczech po II wojnie światowej, Roczniki Biblioteczne (32) 1988, z. 2, s. 141-176; Zdzisław MAREK, Biblioteki polskie w Australii, Pamiętnik Literacki [Londyn] 1988, $\mathrm{nr}$ 12, s. 9-26; Z. GACA-DĄBROWSKA, Tropami organizowania sieci bibliotek polskich na obczyźnie. (Działalność biblioteczna Stowarzyszenia Polskich Kombatantów), Roczniki Biblioteczne (36) 1992, z. 1/2, s. 219-232; Jarosław SOZAŃSKI, Zarys historyczny bibliotek polskich na ziemiach łotewskich, [w:] Kultura polska na Łotwie. Red. J. Sozański, Ryszard Szklennik, Ryga: Ambasada Rzeczypospolitej Polskiej w Rydze 1994, s. 45-51; Helena LEGOWICZ, Polskie biblioteki publiczne na Zaolziu 1956-1989, [w:] Książka na Śląsku w latach..., s. 268-273. Zob. też Wykaz wybranych pozycji bibliograficznych, [w:] Wspótczesne księgozbiory polskie za granica. Informator. 1. Polskie i polonijne księgozbiory instytucji. Oprac. Barbara Bieńkowska, Elżbieta Maruszak, Jacek Puchalski, Warszawa: Ministerstwo Kultury i Dziedzictwa Narodowego 2009, s. 687-701.

312 Sław MILEWSKI, 25 lat działalności Stałej Konferencji Muzeów, Archiwów i Bibliotek Polskich na Zachodzie 1979-2004, Warszawa: Naczelna Dyrekcja Archiwów Państwowych 2006.

313 M.in. A. MĘŻYŃSKI, Biblioteka Polska w Paryżu. Rys historyczny, zbiory, dzień dzisiejszy, Przegląd Biblioteczny 1983, z. 1, s. 13-25; A. KŁOSSOWSKI, Półtora wieku Biblioteki Polskiej w Paryżu. Widziane z Biblioteki Narodowej, Biuletyn Informacyjny Biblioteki Narodowej 1990, nr 3/4, s. 20-27; Jerzy MOND, Towarzystwo Historyczno-Literackie i Biblioteka Polska w Paryżu. Historia i dzień dzisiejszy, Nauka Polska 1991 nr 2, s. 93-116; Adam GAŁKOWSKI, Leszek Talko (1916-2003). O Bibliotece Polskiej w Paryżu, Zeszyty Historyczne 2003, z. 146, s. 120-136; H. ŁASKARZEWSKA, Biblioteka Polska w Paryżu - wędrówki zbiorów w latach 1940-1992, Roczniki Biblioteczne (48) 2004, s. 3-38.

314 Biblioteka Polska w Londynie 1942-1992. Sine litteris mors. Red. Z. Jagodziński, Londyn: Biblioteka Polska Polski Ośrodek Społeczno-Kulturalny 1993.

315 M.in. Roman NIR, Archiwa, biblioteki i muzea Polonii w Orchard Lake, Archiwa, Biblioteki i Muzea Kościelne (62) 1993, s. 113-146.

316 Małgorzata KOT et al., Muzeum Polskie w Ameryce. Dzieje i zbiory, Warszawa: Stowarzyszenie Wspólnota Polska 2003.

317 M.in. Sylwia NEHRING, Polskie Muzeum w Rapperswil, Rapperswil: Towarzystwo Przyjaciół Muzeum Polskiego w Rapperswilu 1976; W. KANTAK, Działalność biblioteki Muzeum Polski Wspótczesnej w Rapperswilu w latach 1945-1951, Acta Universitatis Nicolai Copernici Bibliologia (4) 2000, s. 251-263. 
wego w Ameryce (Biblioteka im. Alfreda Jurzykowskiego) ${ }^{318}$, Instytutu Józefa Piłsudskiego w Londynie ${ }^{319}$, Instytutu Józefa Piłsudskiego w Ameryce ${ }^{320}$ oraz Studium Polski Podziemnej w Londynie ${ }^{321}$. Historia polskiego bibliotekarstwa poza granicami kraju w latach 1945-1989 obejmuje także studia biograficzne ${ }^{322}$. Podejmowane są również badania nad księgozbiorami prywatnymi ${ }^{323}$.

$$
* * *
$$

W 1950 roku A. Birkenmajer stwierdził, że po wojnie ,nie było czasu [...] na twórczą pracę naukową w zakresie księgo- i bibliotekoznawstwa. Toteż plon lat 1945-1950 na tym polu przedstawia się, zwłaszcza w porównaniu z plonem przedwojennym, jeszcze skromnie i ubogo", ponieważ liczba prac ,jest nikła, [...] ich tematyka jest dorywcza, a więc przypadkowa; że większych objętością publikacji nie ma prawie wcale; że opracowania (poza wyjątkami) albo ograniczały się do przyczynków, albo szły po linii najmniejszego oporu, opierając się nie na źródłach pierwszej ręki, lecz na dawniejszych opracowaniach"324.

W kontekście cytowanej wypowiedzi należy stwierdzić, że mimo niedostatków, o których była mowa powyżej, od połowy lat 50 . XX wieku nastąpiła intensyfikacja badań nad historią bibliotek i bibliotekarstwa. Ich wynikiem były monografie, artykuły problemowe i monograficzne, zarysy oraz prace popularnonaukowe wnoszące trwałe wartości merytoryczne i metodologiczne do dorobku polskiej bibliologii. Stało się to możliwe dzięki rozbudowie podstawy źródłowej studiów, rozwojowi refleksji źródłoznawczej i metodologicznej oraz powiększeniu się środowiska zainteresowanego pracami historycznymi. Ten ostatni aspekt wiązał się z powołaniem do życia akademickich ośrodków kształcenia bibliotekarzy i pracami naukowo-badawczymi ich kadry; działalnością wyspecjalizowanych placówek, takich jak np. Instytut Książki i Czytelnictwa Biblioteki Na-

318 Polski Instytut Naukowy w Ameryce. Przewodnik po zbiorach archiwalnych. Oprac. Stanisław Flis, Warszawa: Naczelna Dyrekcja Archiwów Państwowych. Wydział Wydawnictw 2004.

319 Janusz ZUZIAK, Dzieje Instytutu Józefa Piłsudskiego w Londynie 1947-1997, Warszawa: Akademia Obrony Narodowej 2001.

320 Janusz CISEK, Instytut Józefa Piłsudskiego w Ameryce i jego zbiory, Warszawa: Biblioteka Narodowa 1997.

321 Andrzej SUCHCITZ, Informator Studium Polski Podziemnej. Londyn 1947-1997, Londyn: Studium Polski Podziemnej 1997.

322 Zob. m.in. Kustosze księgozbiorów polskich za granicą. Red. Hanna Laskarzewska, Warszawa: Wydaw. SBP 2013.

323 M.in. A. KŁOSSOWSKI, Bibliofilstwo polskie za granica. Wybrane zagadnienia teoretyczne. Organizacje bibliofilskie i oficyny artystyczne, Studia o Książce (19) 1993, s. 43-73; M.A. SUPRUNIUK, Emigracyjny księgozbiór prywatny Józefa Czapskiego i jego znaczenie w badaniach biograficznych, Acta Universitatis Nicolai Copernici Bibliologia (1) 1996, s. 71-106.

324 A. BIRKENMAJER, op. cit., s. 54, 60. 
rodowej, Ośrodek Archiwów, Bibliotek i Muzeów Kościelnych przy Katolickim Uniwersytecie Lubelskim, Zespół do Badań nad Historią i Kulturą Cystersów przy Instytucie Historii Uniwersytetu im. Adama Mickiewicza w Poznaniu oraz Pracownia Badań Nad Dziejami Zakonów i Kongregacji Kościelnych (Larhcor) w Instytucie Historycznym Uniwersy tetu Wrocławskiego; aktywnością naukowo-badawczą bibliotekarzy. Historią bibliotek zajmowali się przy tym (przeważnie jednak pobocznie) także m.in. historycy literatury, nauki, oświaty, kultury, sztuki i architektury, socjolodzy, jak również etnolodzy i filolodzy, zainteresowani np. zbiorami i funkcjami bibliotek polskich na obczyźnie. Ważną rolę w rozwoju badań historycznych, poprzez ich inicjowanie i publikowanie wyników, odegrało czasopiśmiennictwo bibliologiczne (i nie tylko) — ogólnopolskie oraz wydawane przez biblioteki i ośrodki akademickie.

Obecny poziom wiedzy o przeszłości bibliotek i bibliotekarstwa wydaje się z jednej strony sumą indywidualnych dociekań poszczególnych badaczy, z drugiej zaś wynikiem studiów — realizowanych z mniejszą lub większą konsekwencją i natężeniem w poszczególnych okresach — nad priorytetowymi polami badawczymi ośrodków bibliologicznych, zwłaszcza wrocławskiego, warszawskiego, krakowskiego i katowickiego oraz zajmujących się historią zakonów i kongregacji kościelnych.

JACEK PUCHALSKI

AN OVERVIEW OF RESEARCH INTO THE HISTORY OF LIBRARIES

AND LIBRARIANSHIP IN POLAND IN 1945-2015

\section{Summary}

The author of the article discusses selected academic and popular publications concerning the history of libraries and librarianship in Poland which appeared in 1945-2015. In that period information about the most important historical resources of various Polish libraries and early book collections was made available; in addition, the period was marked by progress in the study of materials originating before the end of the 18th century. Scholars published a range of methodological studies as well as studies dealing with sources, contributing to the development of scholarship. On the other hand, there were too few editions of source materials.

After 1989 scholars intensified their efforts to find sources in foreign collections, especially in Lithuania, Belarus, Ukraine, Russia and Germany. Polish collections kept abroad are yet to be fully researched and have their inventories and catalogues published.

The vast body of literature is uneven when it comes to its focus on the various historical periods, regions, subregions and local centres. It comprises publications dealing with the history of libraries, their function and role in culture with regard to the history of the book, and publications focused on the types of libraries or individual libraries — of different traditions, sizes and stature. Scholars also explored the history of home book collections, reading rooms and libraries as well as biographies of librarians and collectors. The quality of the publications varies. There are gaps in, for example, the history of libraries in the former Polish Eastern Borderlands as well as "blank 
pages" in the historiography of Polish librarianship after the Second World War. There is a visible shortage of quantification of phenomena from the past of libraries, despite the fact that there are some possibilities in this respect. What is also needed is development in comparative studies, also in an international perspective, although this would require Polish historians to become more interested than before in the history of librarianship in other countries.

KEY WORDS: history of libraries, history of librarianship, libraries, Poland 